\title{
EPIDEMIOLOGIA E CONTROLE DO MOSAICO (VMM-ME) \\ EM ABOBRINHA-DE-MOITA
}

\author{
VALDIR ATSUSHI YUKI \\ Engenheiro Agrônomo
}

Orientador: Dr. Álvaro Santos Costa

Tese apresentada à Escola Superior de Agricultura "Luiz de Queiroz", da Universidade de São Paulo, para obtenção do título de Doutor em Agrononia, Área de Concentração: Fitopatologia.

PIRACICABA

Estado de São Paulo - Brasil Junho - 1990 
Ficha catalográfica preparada pela Seção de Livros da Divisão de Biblioteca e Documentação - PCAP/USP

\footnotetext{
Yuki, Valdir Atsushi

Y94e Epidemiologia e controle do mosaico (VMM-Me) em abobrinha-de-moita. Piracicaba, 1990.

$84 p$.

Tese - ESALQ

Bibliografia.

1. Abobrinha italiana - Epidemiologia 2. Mosaico em abobrinha italiana - Controle 3. Virus fitopatogênico I. Escola Superior de Agricultura Luiz de Queiroz, Piracicaba
}

CDD 635.62 


\title{
EPIDEMIOLOGIA E CONTROLE DO MOSAICO (VPMYME)
}

EM ABOBRINHA-DE-MOITA

\author{
Valdir Atsushi Yuki
}

Aprovado em: 20/09/1990

Comissāo julgadora:

Prof. Dr. Darcy Martins da Silva ESALQ-USP

Prof. Dr. Sinval Silveira Neto ESALQ-USP

Prof. Dr. Hiroshr Kimati ESALQ-USP

Dr. Alvaro Santos Costa IAC

Dr. Gera walter Muller

IAC

Alvaro Sartos Costa -Orientador- 
Aos meus pais, que sempre me incentivaram;

à minha esposa e filhos, pelo apoio e compreensāo.

$$
\text { DEDICO }
$$




\section{AGRADECIMENTOS}

o autor deseja expressar seus sinceros agradecimentos:

- Dr. Alvaro Santos Costa, pela excelente orientação, senr pre incentivando, disposto a discutir, sugerir e criticar;

- ao Engo Agro Flávio Passini, do Instituto Adventista de Ensino, pela colaboração prestada nos experimentos conduzi dos na Fazenda Lagoa Bonita, Artur Nogueira;

- à Engạ Agrạ Violeta Nagai, pesquisadora do Instituto Agronōmico de Campinas (IAC), pelo auxílio prestado na par te estatistica;

- aos colegas da Seção de Virologia do IAC, pelo apoioe constantes estímulos durante a elaboração deste trabalho;

- aos funcionários de apoio da Seção de Virologia do IAC, que muito contribuiram para o desenvolvimento deste trabalho;

- ao Instituto Adventista de Ensino, pelas facilidades oferecidas na condução dos experimentos;

- ao Departamento de Fitopatologia da Escola Superior de Agricultura "Iuiz de Queiroz", pelas facilidades oferecidas durante o curso de Pós-Graduação;

- ao Conselho Nacional de Desenvolvimento Científico e Tecnológico (CNPq), pela concessão da bolsa de Pesquisa;

- ao Instituto Agronōmico de Campinas, pela oportunidade de aperfeiçoamento. 
LISTA DE FIGURAS $\ldots \ldots \ldots \ldots \ldots \ldots \ldots \ldots \ldots$

LISTA DE TABELAS $\ldots \ldots \ldots \ldots \ldots \ldots \ldots \ldots \ldots \ldots$

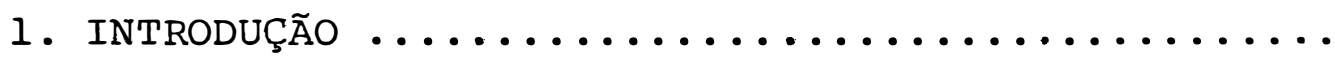

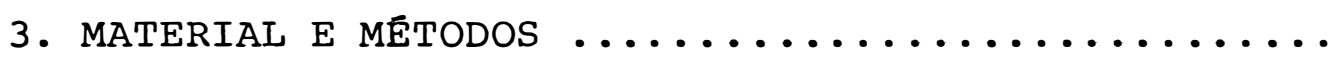

3.1. Avaliação da flutuação populacional das es-

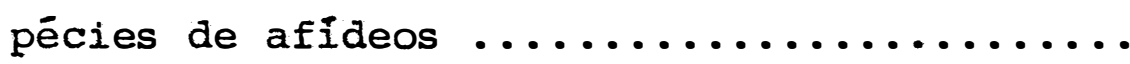

3.2. Determinação da eficiência comparativa de al gumas espécies de afídeos na transmissão do

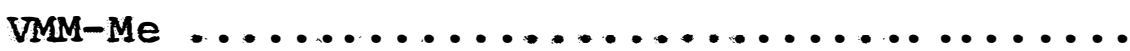

3.3. Produção e exposição das plantas testes em

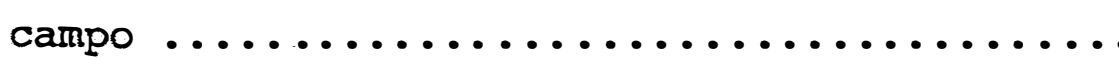

3.4. Controle do VMM-Me através de medidas aplica

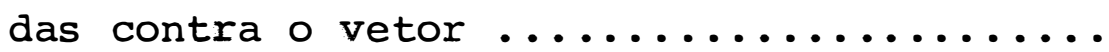

3.4.1. Testes com inseticidas e óleos ...... 23

3.4.2. Testes com substâncias reflectivas .. 25

3.4.2.1. Purpurina dourada e prateada 25

3.4.2.2. Agua de cal ............ 25

3.4.2.3. Casca de arroz aplicada em faixas nas linhas deplantio.

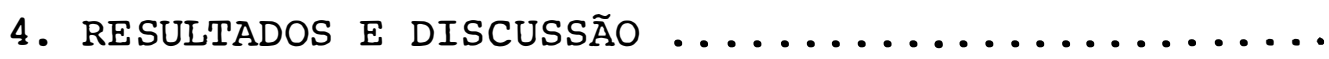

4.1. Flutuação populacional das espécies de afí-

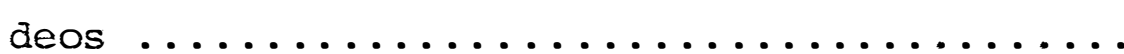


4.1.1. Total anual das espécies mais frequen

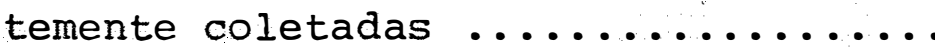

4.1.2. Flutuação mensal no período de janeiro de 1984 a dezembro de 1988 ......

4.1.3. Eficiência comparativa de espécies de afídecs

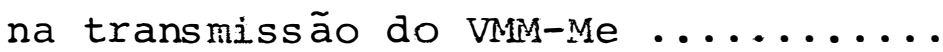

4.2. Correlação entre a incidência da moléstia e a flutuação populacional dos vetores .......

4.3. Controle do VMM-Me através de medidas aplica

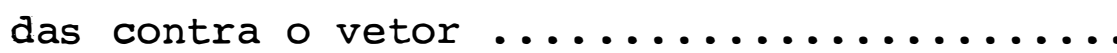

4.3.1. Testes com inseticidas e óleos ......

4.3.2. Testes com substâncias reflectivas ..

4.3.2.1. Efeito da purpurina dourada e prateada ............. 59

4.3.2.2. Efeito da água de cal ......

4.3.2.3. Efeito da casca de arroz apli cada em faixas nas linhas de plantio ..................

5. CONCLUSÕES 


\section{IISTA DE FIGURAS}

FIGURA NO

1 Técnica de transmissão com as diferentes es pécies de afídeos. A - Folha doadora para aquisição do VMM-Me e plantas testes confinadas em manga de lampião. B - Planta infec tada experimentalmente mostrando sintomas

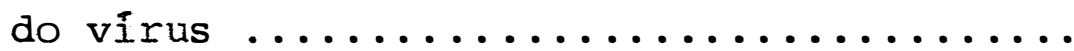

Ensaio de campo com diferentes faixas da su perfície reflectiva de casca de arroz. A Vista geral do campo. B - Faixa de $60 \mathrm{~cm}$. CFaixa de $120 \mathrm{~cm} \ldots \ldots \ldots \ldots \ldots \ldots \ldots \ldots$

Flutuação populacional média, dos anos de 1984 a 1988, đas espécies mais comuns de afídeos alados, coletados em armadilhas de sucção, no Centro Experimental de Campinas.

Incidência mensal do VMM-Me em plantas testes de abobrinha-de-moita e respectivas flu tuações populacionais das espécies vetoras

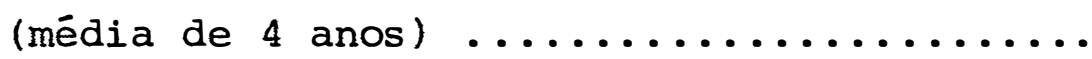

Efeito da casca de arroz aplicada em faixas nas linhas de plantio, no controle do VMMMe, em cultura de abobrinha-de-moita. A Faixas de 0 (testemunha), 60 e $120 \mathrm{~cm}$. B Faixas de 0 (testemunha), 30,60 e $120 \mathrm{~cm}$..

Plantas de abobrinha-de-moita no ensaio com superfície reflectiva de casca de arroz. APlanta infectada. B - Planta sadia ....... 


\section{IISTA DE TABEIAS}

TABELA NO

Pāgina

1 Número total anual de alados de afídeos co letados em armadilha de sucção, das espécies mais comuns, durante os anos de 1984 a 1988, no Centro Experimental de Campinas

Flutuação populacional mensal das espécies mais comuns de afídeos e total das espécies coletadas, durante o ano de 1984 ...

Flutuação populacional mensal das espécies mais comuns de afídeos e total das espécies coletadas, durante o ano de 1985 ....

Flutuação populacional mensal das espécies mais comuns de afídeos e total das espécies coletadas, durante 0 ano de 1986

Flutuação populacional mensal das espécies mais comuns de afídeos e total das espécies coletadas, durante 0 ano de $1987 \ldots$.

Flutuação populacional mensal das espécies mais comuns de afídeos e total das espēcies coletadas, durante o ano de 1988 ....

Eficiência de transmissão do VMM-Me por algumas espécies de afídeos, em compara-

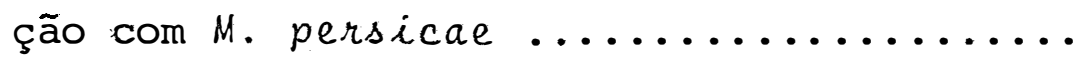

Incidência mensal do VMM-Me, em plantas tes tes de abobrinha-de-moita, no período de $26 / 03 / 84$ a $27 / 03 / 88 \ldots \ldots \ldots \ldots \ldots \ldots \ldots \ldots \ldots \ldots \ldots \ldots$ 
Efeito de dois inseticidas carbamatos, um de aplicação no solo e outro foliar pulve rizado semanalmente, em plantas testes de abobrinha-de-moita, no controle do VMM-Me,

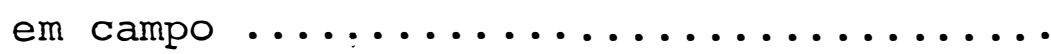

10 Efeito dos inseticidas carbamatos, Aldicarb e Carbofuran, aplicados no solo, sōs ou em combinações com pulverizações de óleos vegetal ou mineral, no controle do

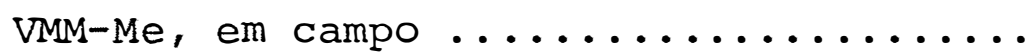

11 Efeito de pulverizações com purpurinas dou rada e prateada, sobre plantas testes de abobrinha-de-moita, no controle do VMM-Me,

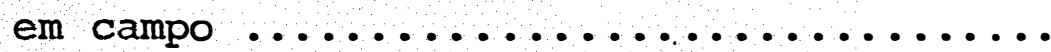

12 Efeito de pulverizações com āgua de cal em plantas testes de abobrinha-de-moita, no controle do $\mathrm{VMM}-\mathrm{Me}$, em campo .........

13 Efeito da casca de arroz aplicada em faixas de 2 larguras, no controle do VMM-Me, em cultura comercial de abobrinha-de-moi-

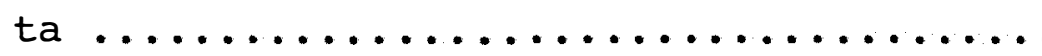

14 Efeito da casca de arroz aplicada em faixas de 3 larguras, no controle do VMM-Me, em cultura comercial de abobrinha-de-moita $\ldots \ldots \ldots \ldots \ldots \ldots \ldots \ldots \ldots \ldots \ldots \ldots \ldots \ldots \ldots \ldots \ldots$ 

xas, na produção da abobrinha-de-moita .. 


\section{EPIDEMIOLOGIA E CONTROLE DO MOSAICO (VMM-Me) \\ EM ABOBRINHA-DE-MOITA}

\section{Autor: VALDIR ATSUSHI YUKI Orientador: ÁLVARO SANTOS COSTA}

RESUMO

O presente trabalho teve como objetivo ampliar os conhecimentos sobre uma virose (VMM-ivie) de cucurbitáceas, que ocorre em culturas de abobrinha-de-moita cv. Caserta |Cucurbita pèpo L.), normälmente em incidências elevadas causando prejuizos aos produtores.

Os experimentos foram conduzịdos nos laborató rios e área de campo da Seção de Virologia do IAC. Aqueles ví sando o controle do vírus através da superfície reflectiva da casca de arroz foram conduzidos na Fazenda Lagoa Bonita, em Artur Nogueira.

Estudos visando determinar a densidade e a flu tuação populacional dos vetores, através da coleta de alados em vôo, por meio de armadilha de sucção, mostraram que as espécies de Aphis foram as mais abundantes, contribuindo com $47,1 \%$ do total, seguidas de Schizaphis graminum $(20,5 \%)$. Rhopal siphum spp. $(\sigma, 9 \circ)$ e Myzus persicae $(6,5 \%)$. Estudos de flutuação populacional (média 84/88) mostraram que os períodos de revoadas mais densas ocorreram em épocas mais ou menos defini- 
das do ano, de acordo com a espécie ou grupo de espécies. Como a revoạda dos afídeos não sofreu interrupção em nenhum mês, aparentemente não existiram fatores que impediram o desenvolvimento dos alados ou que fossem capazes de inibir os vôos. Portanto, a incidência da virose ficou na dependência de fontes de virus.

Os períodos de maiores incidências do VMM-Me, em abobrinha de moita ocorreram do final da primavera (novembro) até meados do outono (maio). Os vetores cuja curva de frequência apresentaram as melhores correlações gräficas coma incidência da moléstia foram as espécies de Aphis e $S$. graminum. As curvas de M. persicae e Rhopalosiphum spp. não apresentaram correlação.

M. persicae foi a espécie mais eficiente experimentalmente na transmissão do VMM-Me, com média de 92,38 , seguida por Aphis fabae solanella $(66,78)$, S. graminum $(50,08)$, A. craccivora $(39,08)$, A. gossypil $(15,48)$ e A. spiraecola $(13,08)$.

Estudos visando controlar o vírus através do controle do vetor mostraram que os inseticidas carbamatos, Al dicarb e Carbofuran, reduziram a incidência do mosaico. Essa redução não foi suficiente para que pudessem ser recomendados. Aplicações foliares de carbamato Pirimicarb, óleo vegetal (Na tur'oil) e mineral (Triona B), as purpurinas dourada e pratea da e ainda a água de cal, não reduziram a incidência do vírus. 
A casca de arroz, aplicada em faixas de 30,60 e $120 \mathrm{~cm}$ ao longo das linhas de plantio, cobrindo respectivamente 25, 50 e $100 \%$ da superfície do solo, retardou a entra da do virus em 1 a 2 semanas nas parcelas, reduzindo significativamente a sua incidência até pelo menos o florescimento. 0 aumento de produção ocorreu também devido ao efeito benéfico como cobertura morta. A utilização da casca de arroz em faixas de 30 ou $60 \mathrm{~cm}$ possibilita seu uso em āreas relativamen te grandes como as da cultura de abobrinha. 


\section{EPIDEMIOLOGY AND CONTROL OF THE MOSAIC (PRSV-W)}

IN ZUCCHINI SQUASH

Author: VALDIR ATSUSHI YUKI

Adviser: ÁLVARO SANTOS COSTA

SUMMARY

The present investigation was undertaken with the purpose of obtaining more information on a mosaic disease of the Zucchini squash (Cucurbita pepo L.) that frequently induces severe losses to the growers. The disease is induced by the papaya ringspot virus - type W (PRSV-W) .

Most of the experiments were carried out at the Virus Department of the Instituto Agronômico, Campinas, SP. Field tests to evaluate control by the use of the reflective surface of rice husks were carried out at Lagoa Boni ta Farm, Artur Nogueira, SP.

Studies to determine the density and populational fluctuation of vectors during the years 1984/88, through the capture of winged aphids with suction traps, showed that the species of Aphis were most abundant, representing $47.1 \%$ of the total. Schizaphis graminum represented 20.5\%, and Rhopalosiphum spp. and Myzus persicae, 6.9 and $6.5 \%$ respectively. The populational fluctuation (average 1984/88), showed that the highest activities occurred at more or less 
definite periods, depending on each species or group studied. Apparently did not exist factors that could inhibit the flight during the year. Thus the dissemination of the virus depends on the presence of source of inoculum.

The highest incidence of the mosaic virus in Zucchini squash plants occurred from the end of spring (November) to middle of autumn (May). Curves representing the monthly density of species of Aphis and $S$. graminum had the best graphic correlation with the monthly incidence of PRSV-W. M. persicae and Rhopalosiphum spp., did not show such a correlation.

M. persicae was experimentally the most efficient vector of the PRSV-W (mean 92.3\%), followed by Aphis babae so lanella (66.78), S. graminum (50.0\%), A. craccivora (39.0\%), A. gossypii (15.6\%) and A. spiraecola (13.0\%).

\section{Studies undertaken to determine methods}

control showed that the carbamate insecticides, Aldicarb and Carbofuran, reduced the virus incidence, but that was not sufficient to merit recommendation. Foliar sprays of the carbamate insecticide Pirimicarb, vegetal (Natur'oil) . and mineral (Triona B) oils, golden and silver dust suspensions,and $10 \%$ whitewash did not reduce virus incidence.

Rice husks, applied in bands of 30,60 and 120 $\mathrm{cm}$ along the line of plants, covering respectively 25,50 and $100 \%$ of the soil surface, retarded by 1 or 2 weeks the PRSV$\mathrm{W}$ appearance in the Zucchini squash plots and consequently 
reduced the incidence of mosaic at least untill the flowering stage. These treatments induced yield gains that were in part due to mulching effect of the rice husks. The use of the rice husks in bands of 30 or $60 \mathrm{~cm}$ makes possible its utilization in large areas as those occupied by zucchini squash crops. 


\section{INTRODUCÃAO}

As cucurbitáceas estão sujeitas a várias doenças causadas por vírus. Dentre essas, uma que causa mosaico nas folhas vem sendo considerada das mais importantes, cau sando prejuízos sensiveis à produção uma vez que as plantas afetadas produzem menos e os frutos, em geral, são de qualida de inferior. Essa moléstia é mais comumente conhecida na lavoura como mosaico-da-abobrinha. O vinus causador foi mais recentemente designado pelo nome "papaya ringspot vírus - type w" (PRSV-W) por PURCIFULL et alii(1984) $\therefore$ A trađuçãa do name desse vIrus em português sugerida por SÃ et alii (1989) é vírus do mo saico do mamoeiro - estirpe melancia (VMM-Me).

Entre as cucurbitáceas, a abobrinha-de-moita (Cucurbita pepo L.) conhecida também como abobrinha-italiana, é uma das mais susceptíveis a esse vírus, que é considerado fator limitante da cultura. A grande vantagem desta espécie de abobrinha é que tem preferência dos consumidores em relação a C. moschata Duchesne, bem mais resistente ao virus. Por outro lado ainda, tem também preferência dos produtores, pois 
apresenta uma sērie de vantagens, como crescimento determinado, formando moitas, o que facilita a colheita e a caminhada dentro da cultura. C. moschata, conhecida também como abo brinha-menina, tem resistência mas apresenta crescimento inde terminado e sua ramagem cobre todo o solo dificultando a cami nhada e a colheita dos frutos que ficam encobertas pelas folhas. Is to faz com que muitos frutos permaneçam no campo; po dendo ser colhidos apenas como abóboras maduras bem mais tarde, ocupando o campo por um período de tempo muito mais longo. Além das vantagens mencionadas as variedades de abobrinha-de-moita são de crescimento rápido, e os frutos podem ser colhidos já aos 40 a 60 dias do plantio, enquanto que para as variedades $c$, moschata as colheitas só se iniciam aos 75 dias. Ainda mais, as variedades de abobrinha-de-moita sao al tamente produtivas e com frequência alcançam melhores preços no mercado. Por todas essas vantagens os produtores paulistas continuam plantando a abobrinha-de-moita, mesmo que a incidência do VMM-Me atinja praticamente toda a cultura ao final do ciclo.

Os experimentos relatados nesta tese, portanto, foram conduzidos visando elucidar aspectos da epidemiologia da moléstia e determinar meios de controle ou de reduzir os prejuízos causados pelo VMM-Me. 


\section{REVISÃO DE LITERATURA}

Aproximadamente 18 vírus diferentes são conhecidos como capazes de infectar naturalmente as cucurbitáceas (LOVISOLO, 1981). No Brasil foram constatados até o momento 6 deles, sendo que o mais comumente encontrado e disseminado, causando grandes prejuízos, é o VMM-Me (COSTA et alii, 1972; ALBUQUERQUE et alii, 1972; ÁVILA, 1982; IIN et alii, 1983; PAVAN, 1985 e CRESTANI et alii, 1987).

o VMM-Me foi designado por PURCIFULL et alii (1984), "papaya ringspot virus - type W", em razão de muitas similaridades com o virus do mosaico do mamoeiro, designado "papaya ringspot vírus - type P". SĀ et alii (1989) sugeriu que $o$ nome desse vírus em português, seja vírus do mosaico do mamoeiro-estirpe melancia (VMM-Me). Nós, apesar de utilizarmos a mesma sigla VyM-Me para o vírus, usamos o nome da molés tia como mosaico da abobrinha, devido ao seu uso normal nas conversas com os pesquisadores e principalmente com os lavradores.

o VMM-Me é um potyvirus constituído de RNA. 
Suas partículas filamentosas têm de 700 a $800 \mathrm{~nm}$ de comprimen to por $12 \mathrm{~nm}$, de diâmetro. Esse vírus induz inclusões amor fas e cilindricas, do tipo catavento, no citoplasma das células hospedeiras (VAN REGENMORTEL et alii, 1962). A sintomato logia nas plantas depende da espécie de cucurbitácea afetada. Ela é mais severa em $C$. pepo, e se traduz por leve clorose e clareamento das nervuras das folhas, evoluindo para mosaico, clorose interneval, formação de bolhosidades ou ilhas verdes mais escuras e deformações filiformes das folhas. Além disso, o desenvolvimento das plantas é severamente afetado (ANDERSON, 1954 e VAN REGENMORTEL et alii, 1962). As plantas afe tadas têm sua produção reduzida tanto em qualidade como em quantidade, ou seja, o número e tamanho dos frutos são bem menores, podendo ainda estarem manchados e deformados, reduzindo assim o seu yalor comercial (GEORGE \& KRING, 1971 costA et alii, 1972). Estudos feitos por YUKI \& $\operatorname{cOSTA}^{1}$ mos traram que a produção foi severamente afetada quando plantas de abobrinha-de-moita (cy. Caserta) eram infectadas antes do florescimento. Após o florescimento a redução tanto no pe so como no número de frutos comerciais não foi significativa. Muitas espécies de afídeos estão envolvidos na transmissão do VMM-Me. KARL \& SCHMELZER citados por PURCIFULL et alii (1984), listaram 24 espécies. E um vírus de re-

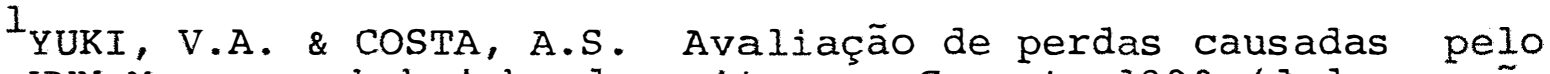
VMM-Me, em abobrinha-de-moita cv. Caserta, 1990 (dados não publicados).
} 
lação não persistente com o vetor, ou seja, è adquirido e ino culado muito rapidamente, em questão de segundos. Tem também um período de retenção relativamente curto de poucas horas e o jejum antes da aquisição melhora a eficiência do vetor. Essa eficiência também varia de acordo com a espécie, sendo que Myzus persicae (Sulz.) e Aphis gossypii Glover, são considera das as mais eficientes. Apesar disso, outras espécies como Aphis spiraecola Patch e Aphis craccivora. Koch, apresentam eficiência relativamente alta, acima de 50\% (ADLERZ, 1974; SAKO et alii, 1977). A eficiência aparentemente também varia entre regiões ou países. MILNE \& GROGAN (1969) verificaram uma eficiência de transmissão de $M$. persicae entre 30 e $70 \%$, em três repetições, enquanto que ADLERZ (1974) obteve uma eficiência média de 698 e SAKo et alii (1977), 1008 de eficiência. Para A. gossypii e A. craccivora, as eficiências obtidas por estes autores foram bastante semelhantes.

Estudos visando correlacionar incidência de vỉrus transmitidos por afídeos de relação não persistente on apenas una espécie do vetor, não têm tido sucesso esperado uma vez que esses vírus são transmitidos por um número relativamen te grande de espécies (BROADBENT, 1950). IRWIN \& GOODMAN (1981) sugerem que os estudos devem ser feitos com as espécies mais abundantes e que sejam vetores do vírus. Além disso, há necessidade de correlacioná-los com a eficiência de cada espécie.

ADLERZ (1974), estudando a epidemiologia de 
VMM-Me em cultura de melancia (Citrullus vulgaris Schrad), dis cute a dificuldade de correlacionar a incidência do vírus de relação não persistente com a da população vetora. Considerou M. persicae como um dos vetores mais importantes, porque além de ter sido um dos mais eficientes nos testes de laboratório, consistentemente foi uma das espécies mais abundantes nos 10cais onde os experimentos foram conduzidos. A. spiraecola, que eventualmente desenvolve grandes populações, foi também consi derado importante vetor. Discute ainda que os resultados obtidos no trabalho são característicos de transmissão por vetor que voa de fora para dentro, e adquire o vírus de outra cul tura. A. gossypie, única espécie vetora que coloniza melancia na Flórida, EUA, è bem controlada, tornando-se um fator de pouca importância na disseminação dentro. Além disso, a população de alados dessa espécie coletados em armadilhas ama relas de água foi insignificante, durante o período de 66 a 71 quando se realizaram os estudos naqueles locais.

Embora se desconheçam estudos de epidemiologia do VMM-Me no Brasil, conhece-se a densidade e a flutuação po pulacional de algumas espécies vetoras, principalmente em são Paulo. COSTA \& COSTA (1972a), através da coleta de alados de afídeos, em armadilhas amarelas de água em Campinas, SP, verificaram que as espécies Brevicoryne brassicae(L.), M. persi cae e Toxoptera citricidus (Kirk.), contribuíram com 45,5\% do total das coletas. Somando a estas as espécies dos gêneros Aphis, Dactynotus e Rhopalosiphum, obtiveram a elevada propor 
ção de 92,5\%. Dentro do gênero Aphis, as espécies A. gossypii, A. craccivora e A. spiraecola, consideradas vetoras, foram as mais abundantes.

A flutuação populacional de M. persicae em Cam pinas, SP, é conhecida (COSTA, 1970). Os períodos de maiores revoadas ocorrem nos meses de abril a setembro, com o pico no mês de maio. Eventualmente revoadas significativas podem se dar no mês de dezembro e aparentemente estão associadas a tem peraturas mais baixas que podem ocorrer nesse mês em alguns anos (COSTA \& COSTA, 1972b). O período de maiores revoadas dessa espécie coincide com o de maiores incidência dos vírus causadores de amarelos em tomateiro (amarelo baixeiro e topo amarelo), pois, segundo costa et alii (1964), os meses de maior incidência vão de março a setembro. Por outro lado ain da, estudos comparativos entre armadilha amarela de água e de sucção (CosTA, 1970), mos traram que aquela sempre coletou maior número de alados de M. persicae do que a sucção. Entretanto, as curvas que representam as variações semanais e mensais das duas armadithas apresentaram as mesmas formas.

COSTA \& COSTA (1972b) também estudaram a flutuação populacional das espécies do gênero Aphis e verifica ram ocorrer dois picos na curva de revoadas: o primeiro entre abril e junho e o segundo em dezembro. Esses autores observa ram que como as espécies de Aphis foram estudadas em conjunto, pode ter acontecido de uma delas ter sido predominante em um pico e o outro representar a migração de uma outra. 
Vários métodos de controle das fitoviroses trans-' mitidas por afídeos são conhecidos. ZITTER \& SIMONS (1930) e RACCAH (1986) fizeram revisões sobre o assunto e, apesar de o número de métodos ser relativamente grande, os mais viáveis para a cultura de abobrinha-de-moita, cujo controle deve ser concentrado no início da cultura até o florescimento, são o controle através de defensivos (inseticidas e óleos) e as substâncias reflectivas.

Tradicionalmente o uso de inseticidas é recomendado para o controle de afídeos vetores. Entretanto, de uma maneira geral, é reconhecido que para os vỉrus de relação não persistente com o vetor não têm tido efeito na redução da incidência desses fitovírus (BROADBENT, 1957 e PACCAH, 1986). A explicação é de que os recomendados, que normalmente são os organofosforados, não são suficientemente rápidos para matar os vetores antes da inoculação dos vírus. Em certos casos ainda podem até aumentar a incidência dos vỉrus por eles transmitidos, em consequência da excitação causada pelos inse ticidas durante as picadas de prova.

Estudos visando reduzir a incidência do VMM-Me e do vírus do mosaico da melancia-2 (VMr-2), en cucurcitáceas, através de inseti cidas, têm sido contraditórios. MESSIAEN et alii(1967)e DAIBER \& DONALDSON (1976) comentam em seus trabalhos que testaram os inseticidas fosforados (Demeton-s-methyl, Methyl-parathion, Mevinphos, Di methoate e Isolan), e que estes foram incapazes de reduzir ou retardar a entrada do virus na cultura. Por outro lado, CHAL 
FANT et alii (1977) testaram, durante dois anos seguidos, o Carbofuran aplicado no solo plantado com a abobrinha-de- moita. No primeiro ano não verificaram redução significativa na incidência do vírus, tanto nas plantas como nos frutos colhi dos. Entretanto, no segundo ano, verificaram uma redução sig nificativa no número de frutos com sintomas. Não foram feitas observações de incidência nas plantas. Os autores acharam que essa redução aparentemente se deu em razão da menor disseminação secundária dentro do campo. Finalmente, WYMAN et alii (1979) pulverizaram semanalmente o inseticida Demeton -s-methyl em abobrinha-de-moita e verificaram um pequeno aumento sem significância estatística na incidência do VMM- 2 .

Apōs a descoberta de BRADLEY et alii (1962), de que óleo pulverizado sobre plantas de batata (Solanum tubero sum I.), interferia na transmissão do vírus Y da batata ("Po tato vírus $\mathbf{Y}$ - PVY"), vários outros se seguiram e tem sido um dos mētodos recomendados para o controle dos vírus da reliação não persistente (ZITTER \& SIMONS, 1980 e RACCAH, 1986). Segun do SIMONS \& ZITTER (1980) a aplicação de óleos é recomendada e utilizada comercialmente na Europa e Israel em batata-semente, İ́rio (Lilium sp.), pimentão (Capsicum annuum L.). e pepino (Cucumis sativus L.). Nos EUA, em pimentão, aböbora e tomate (Lycopersicon esculentum Mill.) com excelentes resultados (ZITTER \& SIMONS, 1980). Entretanto o uso ainda não é tão dî fundido em razão da perda ou falta de eficiência em várias oca siões e tambēm devido à fitotoxicidade. MARROU \& MESSIAN (1968) 
pulverizaram óleo mineral a $2 \%$ em plantas de melão e abobrinha e não verificaram redução na incidência em relação às testemu nhas. CHALFANT et alii (1977) pulverizando semanalmente óleo mineral a $1 \%$ obtiveram resultado negativo no primeiro ano e positivo no segundo ano em plantas de abobrinha-de-moita. WYMAN et alii (1979) pulverizaram óleo mineral a 2 e $4 \%$, duas vezes por semana, em plantas de abobrinha-de-moita e, apesar de $\circ$ tratamento a $4 \%$ ter retardado a entrada do VMM-2, a produção foi comparável à das testemunhas.

As substâncias refletivas têm sido bastante in vestigadas no controle dos virus transmitidos por afídeos em cultura de abobrinha. Os resultados têm sido satisfatórios. As pesquisas com esses produtos, principalmente superficies a luminizadas, praticamente se iniciaram quando KRING (1964) verificou que armadilhas amarelas de água quase não cole tavam afídeos quando circundadas com bandejas de aluminio. Ve rificou ainda que as coletas eram drásticamente reduzida quan do as armadilhas foram colocadas sobre plásticos de cores laranja ou preto, em relação às armadilhas diretamente sobre o solo. O autor achou que esses resultados poderiam ter aplica ções bastante práticas no controle das fitoviroses transmitidas por afídeos, visto que a simples alteração da reflectância e a cor do "background", poderiam induzir os afídeos em vôo a não descer nas culturas.

Apesar de as pesquisas sobre substâncias reflectivas terem se intensificado após KRING (1964), a desco- 
berta de que superfícies de cores diferentes afetavam a cole ta em armadilhas amarelas de água havia sido feita anterionnen te por MOERICKE (1954), quando verificou que circundando arma dilhas amarelas de água com tecidos de diferentes cores, havia menor coleta nas armadilhas. Sobre tecido azul a coleta era apenas 3\% do total coletado sobre a armadilha colocado so bre o solo, seguida pelo branco (7\%), preto (29\%) e amarelo $(40 \%)$. Nesse mesmo trabalho verificou que uma faixa branca de apenas $7 \mathrm{~cm}$ ao redor das armadilhas tinha grande influência no comportamento dos afídeos em vôo, reduzindo em $91 \%$ as coletas. Uma faixa de $20 \mathrm{~cm}$ reduziu 99\%, quando comparada com armadilhas colocadas sobre o solo limpo.

O primeiro trabalho sobre a utilização de repe lentes reflectivos encontrado foi de SMITH et alii (1964), quan do aplicaram folhas de aluminio nas linhas de plantio de gladiolos (Gladiolos sp.) e de una composta Vernonia anthelminti ca e verificaram uma drástica redução no número de afídeos co letados em armadilhas amarelas de água, respectivamente 96 e 98\%, quando comparadas com armadilhas colocadas em canteiros que não receberam material algum (solo limpo). Paralelamente a essas observações, verificou-se uma redução de $67 \%$ na in cidência do vírus do mosaico do pepino ("cucumber mosaic víns - CMV") nos canteiros de gladíolo com alumínio. Pelo menos 12 espécies de afídeos foram repelidas. Pulverizações com pó de aluminio foram tão eficientes quanto as folhas, entretanto, tiveram a desvantagem de perder aderência em 2 a 3 dias. 
O nümero de trabalhos utilizando substâncias re flectivas em cucurbitáceas visando controlar as viroses trans mitidas por afídeos é relativamente grande. A maioria utiliza superfícies aluminizadas e plásticos de cores variadas (MOO RE et alii, 1965; MESSIAN et alii, 1967; WOLFENBARGER \& MOORE, 1967; ADLERZ \& EVERETT, 1968; MARROU \& MESSIAN, 1968; GEORGE \& KRING, 1971; DAIBER \& DONALDSON, 1976; CHALFANT et alii, 1977 e WYMAN et alii, 1979). Todos eles obtiveram êxito no controle. Entretanto DICKSON \& LAIRD (1966) discutem que nas condições em que efetuaram o teste, o uso de superfícies aluminizadas não teve valor prático, apesar de o alumínio ter retardado a entrada do vírus de 5 a 10 dias na cultura de melão.

A casca de arroz é um outro produto reflectivo que pode ser utilizado com grandes vantagens sobre as superfícies aluminizadas ou os filmes plásticos, principalmente pelo baixo custo de aquisição. Este produto foi descoberto por COSTA (1969a) quando realizou uma série de estudos visando encontrar coberturas vegetais ou outro material de fácil obtenção nas áreas agrícolas e que repelisse os afídeos. Os resultados mostraram que a easca de arroz reduziu em cerca de $95 \%$ a coleta de M. persicae alados na armadilha amarela colocada sobre ela, em relação à armadilha colocada sobre o solo limpo. Quanto à incidência dos vírus causadores de amarelos em tomateiros, nos canteiros controles foi de 48\%, e naqueles em que se encontrava a casca de arroz, nenhuma das 
plantas foi infectada. Esses resultados foram confirmados pos teriormente pelo mesmo autor (COSTA, 1972a), em outros ensaios realizados em épocas diferentes.

A casca de arroz também mostrou-se eficiente no controle do VMM-Me em canteiros de abobrinha-de-moita, atrasan do em aproximadamente um mês e sua introdução na cultura. Hou ve aumento na produção de frutos, de 41 nas parcelas sobre 0 solo limpo (testemunhas) para 252 nas parcelas protegidas com a casca de arroz (COSTA \& COSTA, 1971). COSTA (1972a) confir mou esses resultados quando verificou também um atraso na introdução e menor incidência do vírus e redução drástica na coleta de Aphis spp. sobre as armadilhas instaladas sobre a casca de arroz.

Apesar do efeito satisfatório da casca de arroz no controle das fitoviroses transmitidas por afídeos, seu uso ainda é restrito aos canteiros de mudas (COSTA, 1972a,b), pois, a quantidade necessária para cobrir toda a área de uma cultura seria muito grande e praticamente impossivel de se conseguir. Entretanto, essa casca de arroz poderia ser utili zada em faixas, ao longo das linhas de plantio, e em quantidades menores. CosTA (1972b) verificou que uma camada delgada, suficiente para cobrir o solo com a casca de arroz, foi suficiente para produzir o efeito máximo em reduzir o pouso de migrantes das espécies mais sensíveis. Verificou também que uma faixa de $12,5 \mathrm{~cm}$ de casca de arroz, circundando as ar madilhas, foi suficiente para produzir o efeito reduzindo a 
descida de alados de várias espécies, incluindo Aphis spp. e M. persicae; uma faixa de $25 \mathrm{~cm}$ de largura já produziu efeito considerável, enquanto que para uma faixa de $50 \mathrm{~cm} \circ$ efeito foi máximo, não diferindo de faixas com 100 e 200 cm de largura.

A aplicação de cal em pulverizações foi testada como repelente reflectivo. MARCO (1986) pulverizou semanalmente parcelas de uma cultura de batata com uma solução de cal a 15\% e verificou uma redução na incidência do vírus do enrolamento da folha da batata ("potato leaf roll virus-PLRV"), que tem relação persistente, de até 6lo. Com o PVY, que tem relação não persistente, foi de até 68\%. Em um dos 7 testes independentes para $\bigcirc$ PLRV e também em um dos 4 testes para 0 PVY, não houve resposta. A aplicação do cal causou redução média na produção de tubérculos de $30 \%$.

O sucesso da aplicação de substâncias reflectí cas depende de vários fatores. KRING (1972) destacou três de les: a) ocorrência de revoadas com número excepcionalmente al to de afídeos vetores. Apesar da comprovada repelência aos afídeos das superfícies repelentes, sempre uma proporção deles desce sobre a cultura sob sua proteção. Portanto, quanto maior o número nas revoadas, maior o número dos que descem sobre as plantas aumentando também a incidência; b) redução da área repelente em razão do crescimento vegetativo. A maio ria dos trabalhos inostram que após certo tempo do plantio há uma perda gradativa da repelência, aumentando bastante a inci 
dência do vírus, chegando a ser comparável às testemunhas (MOORE et alii, 1965; WOLFENBARGER \& MOORE, 1967; ADLERZ \& EVERETT, 1968; GEORGE \& KRING, 1971 e WYMAN et alii, 1979). Portanto, O objetivo principal das superfícies repelentes colocadas no so lo seria o de evitar a infecção precoce das plantas; c) as plantas crescem verticalmente e se distanciam mais da camada protetiva do solo que começa a perder o efeito. o efeito em altura da camada protetiva segundo KRING (1970) e GEORGE \& KRING (1971) com superfícies aluminizadas, foi de $50 \mathrm{~cm}$. Aci ma dessa distância esse efeito é diminuído. Costa (1972b), utilizando casca de arroz, verificou que as espécies mais sen síveis eram afetadas até pelo menos 1,0 m acima do nível.

As espécies de afídeos também devem ser consideradas. ADLERZ \& EVERETT (1968), apesar de observarem uma re dução significativa na incidência do VMM-Me em parcelas de melancia com superfície plástica branca, verificaram um aumento na coleta de afídeos nas armadilhas. A explicação dada por esses autores foi de que a espécie ou espécies atraías sobre essa superfície não eram vetoras do VMM-Me. COSTA (19720) verificou que a reação das espécies de afídeos à casca de arroz variou. Os pulgões M. persicae, T. citricidus, B. brassicae, Dactynotus spp. e Geopemphigus floccosus Moreira foram as espécies mais sensitivas. Aphis spp. e Rhopalosiphum spp. foram menos sensiveis, enquanto que Schizaphis graminum (Rond) e Melanaphis (Longiunguis) sacchari (Zohntnex) foram indiferen tes, havendo até uma tendência para descerem em maior número 
em armadilhas operando sobre a casca de arroz. MARCO (1986) verificou que em parcelas de pimentão (Capsicum annuum L.) pulverizadas com cal, o número de alados de 3 espécies coletadas em armadilha amarela de água (A. spiraecola, $M$. persical e Aphis fabae Scopoli), foi reduzido; uma não mostrou alteração (A. craccivora); e uma espécie foi coletada em maior número (A. gossypii). 


\section{MATERIAL E MÉTODOS}

3.I. Avaliação da flutuação populacional das espécies de afídeos

A captura dos afídeos alados em vôo foi efetua da através de uma armadilha de sucção de Johnson e Taylor (JOHN SON \& TAYLOR, 1955), fabricada comercialmente na Inglaterra. Esta armadilha foi instalada em uma área experimental de campo Iocalizada próximo à Seção de Virologia do Instituto Agronômico de Campinas (IAC), longe de construções e grandes ārvores e livres de vegetação num raio aproximado de $10 \mathrm{~m}$.

o recipiente coletor de insetos contendo uma mistura de álcool 96\%, água e glicerina, nas proporções de 80 , 15 e 5\% respectivamente, era substituído diariamente às 7:30 da manhã. O recipiente com os insetos era levado ao laboratoo rio onde separavam-se os afídeos de outros insetos visualmente. A seguir, com auxílio de um estéreo-microscópio de 7 a 30 aumentos os afídeos eram identificados ao nível de espécie ou gènero, anotando-se os números de cada um deles en protoco- 
lo diário. As coletas foram realizadas no período de 18 de janeiro de 1984 a 31 de dezembro de 1988 .

Ao final do período de coletas, os grupos foram somados mensal e anualmente e os mais abundantes analisados separadamente. Primeiramente analisaram-se os totais anuais e depois os totais mensais a fim de se determinar a flu tuação populacional.

3.2. Determinação da eficiência comparativa de alguras espécies de afídeos na transmissão do VMM-Me

Foram testados 4 espécies de Aphis: A. craccivora, A. fabae solanella Tehobald, A. gossypii e A. spiraecola; e também a espécie $M$. persicae, por serem os vetores mais conhecidos e abundantes. S. graminum foi testado posterione? te em razão da abundância com que foi capturado na armadilha de sucção.

Todas essas espécies testadas foram criadas so bre plantas sadias em insetários na seção de Virologia do IAC. A. craccivora, em plantas de feijão-de-corda (Vigna sinensis EndI.); A. Gabae solanella, em maria-preta (Solanum americanum Mill.); A. gossypii, em algodão (Gossypium hirsutum L.), A. spiraecola, em mudas de rabanete-selvagem (Raphanus raphanistrum L.) e S. graminum, em plantas de sorgo (Sorghum bicolor Pers.). 
As inoculações foram feitas sempre comparativamente, aos pares, tendo como padrão M. persicae.

Como fonte de inóculo utilizou-se o VMM-Me, iso lado 1, da coleção da Seção de Virologia do IAC, mantida cons tantemente atravēs de inoculações mecânicas em plantas de abo brinha-de-moita cv. Caserta. Como planta teste utilizaram-se tambēm plantas de abobrinha-de-moita cv. Caserta com início de desenvolvimento das primeiras folhas verdadeiras. Em cada teste foram utilizadas 20 plantas por espécie de afídeo e repetido 3 vezes em datas diferentes.

Os testes foram feitos retirando-se a espécìe desejada de afídeo das plantas hospedeiras com auxílio de um. pincel fino e macio (marca Tigre, pêlo de marta no l ou 2) e colocados em jejum, numa caixa plástica, por um período de 1 hora aproximadamente. Paralelamente o mesmo procedimento era feito para M. persicae. A seguir, os afídeos eram colocados sobre folhas destacadas de abobrinha-de-moita afetadas com 0 VMM-Me para adquirirem o virus, por cerca de 10 minutos, quan do então com auxílio do pincel, 10 indivíduos eram colocados por planta teste. Ao final de cada inoculação as plantas foram cobertas com um vidro de lampião com tela fina de náilon na sua parte superior e etiquetada (Figura lA). Foram assim deixadas por uma noite. Na manhã seguinte as plantas eram pul verizadas com uma solução de Mevinphos (Phosdrin 185CE), na dosagem de 1 cc/litro de āgua, para eliminar os afídeos. Em seguida as plantas eram levadas para casa de vegetação e manti- 


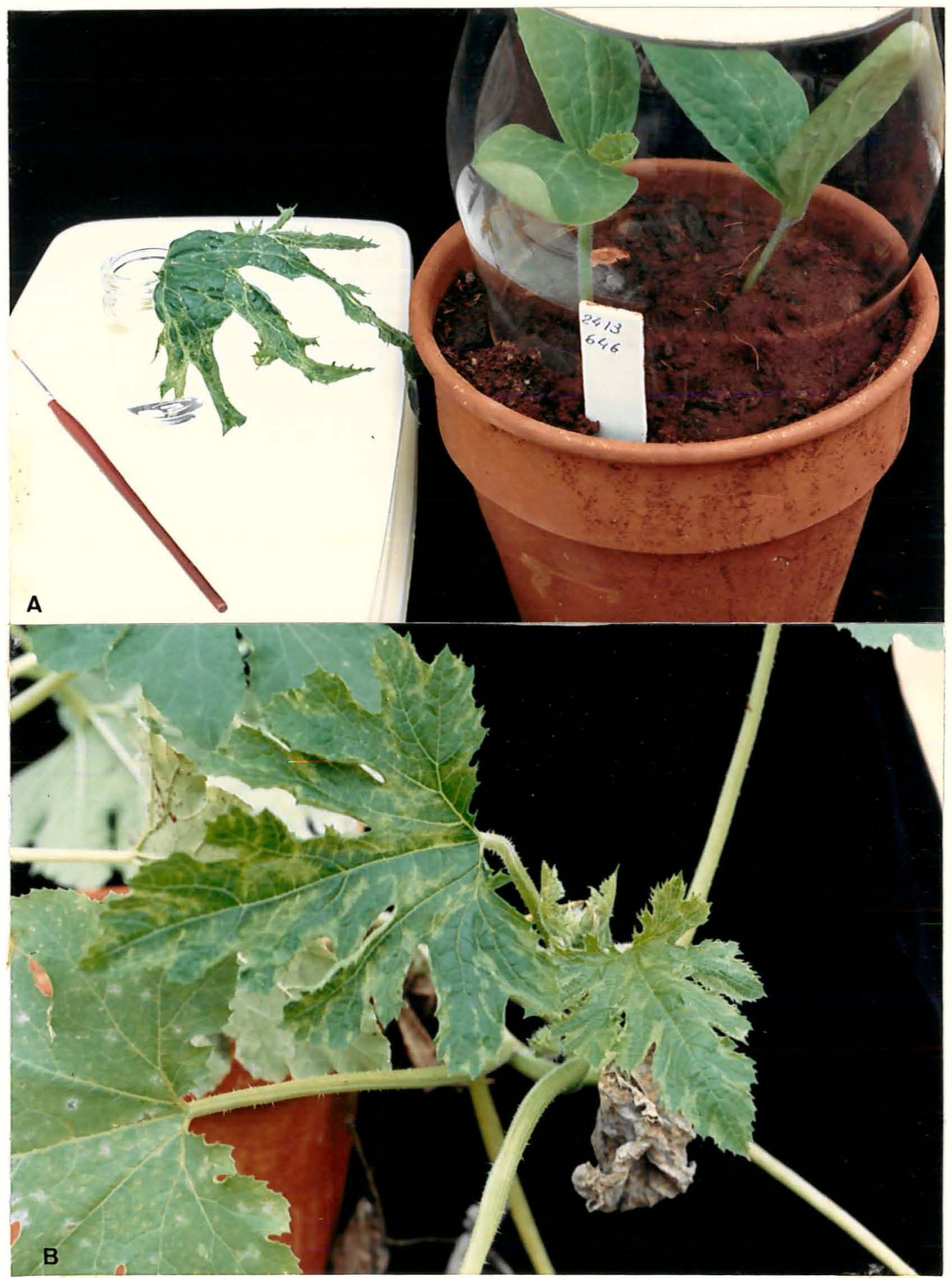

Figura 1. Técnica de transmissão com as diferentes espécies de afídeos. A - Folha doadora para aquisição do VMM-Me e plantas testes confinadas em manga de lampião. B - Planta infecta da experimentalmente mostrando sintomas do vỉrus. 
das por cerca de 4 semanas. Efetuaram-se protocolos semanais anotando-se as plantas afetadas (Figura lB) e mortas.

A fim de se determinar a eficiência de cada espécie testada, calcularam-se as porcentagens de transmissão das mesmas em cada um dos testes pareados com M. persicae. Não foram incluídas nos cálculos as plantas que morreram no trans correr dos testes. Finalmente, considerando indice 100 para M. persicae, elaborou-se uma tabela comparativa de eficiência de transmissão.

\subsection{Produção e exposição das plantas testes em campo}

Como planta teste utilizou-se abobrinha-de-moi ta CV. Caserta, por ser uma das mais susceptíveis ao VMM-Me e a mais plantada dentro desta espécie.

Foram plantadas 4 sementes equidistantes entre si em vasos cônicos de alumínio, com $15 \mathrm{~cm}$ de diâmetro de boca por $16 \mathrm{~cm}$ de altura, contendo uma mistura de solo e esterco curtido na proporção aproximada de 4:1. Após a germinação apenas duas plantas eram deixadas se desenvolver, desbastando-se as restantes. Durante esse período as plantas foram mantidas em condições protegidas de casas de vegetação, a fim de se evitar infecções com vírus. Semanalmente ainda, eram pulverizadas com 0 inseticida Mevinphos, de curto poder residual. As plantas apresentavam 1 ou 2 folhas verdadeiras em de senvolvimento quando eram levadas para o campo. 
Noventa vasos eram distribuídos num campo prōximo à Seção de Virologia do IAC, perto da armadilha de sucção, em 9 grupos de 10, numa ārea de cerca de $400 \mathrm{~m}^{2}$ (20x20m) . Os vasos foram enterrados até a altura da borda em duas linhas de 10 vasos. Portanto, cada grupo ficou constituído de 20 plantas. Dentro do grupo, os vasos se distanciavam entre si de $30 \mathrm{~cm}$.

Esse procedimento foi repetido mensalmente entre os dias 26 e 30 de cada mês, sempre colocando novos vasos com plantas nos mesmos buracos que tinham tido vasos no mês anterior. Os vasos com as plantas retiradas recebiam pulverizações com o Mevinphos, a fim de eliminar possíveis colônias de afídeos. A seguir eram levados à casa de vegetação onde permaneciam por cerca de 4 semanas. Durante esse período, também recebiam pulverizações semanais com Mevinphos e uma adu bação nitrogenada no solo. Protocolos frequentes, em geral semanais, eram realizados obseryando-se o aparecimento dos sintomas de mosaico nas plantas. Plantas que apresentavam sin tomas duvidosos, eram analisadas atrayés de testes biológicos ou ao microscópio eletrônico.

Dos nove grupos, 3 sempre permaneceram sem receber tratamento algum, e foram utilizados nos estudos para determinação da incidência mensal do VMM-Me. Os outros 6 recebiam tratamentos, conforme planos experimentais a serem des critos posteriormente. Os experimentos foram realizados no período de $26 / 03 / 84$ a $27 / 03 / 88$. 
Para os estudos de correlação com a incidência dos vírus, utilizaram-se os dados médios mensais dos anos de coleta na armadilha de sucção. Os estudos fóram realizados com as espécies de Aphis, Rhopalosiphum, M. persicae e S. graminum.

3.4. Controle do VMM-Me através de medidas aplicadas contra o vetor

3.4.1. Testes com inseticidas e óleos

Foram utilizados para os testes canteiros seme Thantes ao teste de exposição.

No primeiro experimento foram testados os inse ticidas carbamatos Aldicarb (Temik 10G) na dose de 0,5 $\mathrm{g}$, apli cado no solo do vaso no primeiro dia da exposição e o Pirimicarb (Pirimor) em pulverizaçōes semanais na dose de 0,5 g/ litro de água. Utilizaram-se neste experimento 3 canteiros por tratamento, representando portanto, 3 repetições por exposição. O experimento teve duração de 17 exposições, ou seja, de 28/11/84 a 27/04/86. A cada exposição a posição dos trata mentos era modificada. Os outros 3 canteiros serviram de tes temunhas e não receberam tratamento algum. As plantas levadas à casa de vegetação receberam os mesmos tratamentos já des critos anteriormente e os protocolos também foram feitos da mesma forma. Os resultados foram analisados mensalmente, com 
o total de plantas das três repetições e por tratamento. Não se consideraram nos cálculos as plantas mortas durante o experimento.

No segundo experimento foram testados os inseticidas carbamatos de aplicação no solo, Aldicarb (Temik 10G), na dose de 0,5 g por vaso e Carbofuran (Furadan 5G), na dose de $1,0 \mathrm{~g}$ por vaso, sōs ou em combinação com óleo mineral (Trio na B) e óleo vegetal (Natur'oil), ambos na concentração de 1\%. Os canteiros utilizados foram idênticos aos dos testes de exposição, um foi tratado com o Aldicarb, o outro com Carbofu ran e um terceiro não recebeu inseticida. Cada canteiro foi subdividido em dois grupos de 5 vasos (2 linhas de 5 vasos) e em uma linha pulverizou-se o óleo mineral e na outra o óleo vegetal. O intervalo de aplicação foi e uma semana sendo repetido após chuvas. Como testemunhas sem aplicação de inseti cidas e óleos, foram utilizados os dados de 5 vasos de cada uro dos 3 canteiros dos testes de incidência e sempre aqueles que estivessem mais próximos e paralelos aos tratamentos. A cada exposição a posição dos tratamentos era modificada. As plantas recolhidas à casa de vegetação recebiam os mesmos tra tamentos já descritos. Os resultados foram analisados através do total de plantas nas 20 exposições mensais, de 28/06/ 86 a 27/01/88, excluindo-se as mortas. 


\subsubsection{Testes com substâncias reflectivas}

\subsubsection{Purpurina dourada e prateada}

No presente experimento testaram-se purpurinas dourada e prateada em pulverizações sobre as plantas de abobrinha-de-moita. Nos canteiros dos testes de exposição, as plantas de 3 deles foram pulverizadas com a purpurina dourada; outros 3 com a prateada e as 3 restantes do teste de incidência representaram as testemunhas. As quantidades utilizadas foram respectivamente, 3,0 e 2,0 gramas aproximadamente das purpurinas dourada e prateada. Essas purpurinas eram mis turadas em I litro de água e pulverizadas com um pulverizador manual de pressão constante, agitando sempre para que a mistú ra permanecesse homogênea. Essa quantidade era suficiente pa ra que as plantas adquirissem coloração dourada ou prateada. o experimento teve duração de 8 exposições mensais, ou seja de $26 / 03$ a $27 / 11 / 84$. O procedimento com as plantas e os protocolos foram iguais aos já descritos. Os resultados foram a nalisados mensalmente com o total das três repetições e por tratamento.

\subsubsection{2. Água de cal}

Este experimento foi conduzido no mesmo perío do em que foram testados os inseticidas de solo e os óleos. Nos três canteiros restantes, subdividiu-se cada um deles em dois grupos de 5 vasos (2 linhas de 5 vasos). Um dos gru- 
pos foi pulverizado com uma solução de 10\% de cal hidratada, usada normalmente nas construções e o outro grupo de 5 vasos constituiu a respectiva testemunha. A concentração de cal utilizada foi suficiente para tornar as plantas visualmente esbranquiçadas. O experimento teve a duração de 20 exposi ções mensais, ou seja, de 28/05/86 a 27/01/88. O restante dos procedimentos foi igual ao descrito para o experimento anterior, inclusive a análise dos resultados.

3.4.2.3. Casca de arroz aplicada em faixas nas linhas de plantio

Foram conduzidos dois experimentos visando verificar o efeito da casca de arroz aplicada no solo ao longo das linhas de plantio em faixas de larguras variáveis. Ambos foram conduzidos em uma cultura comercial de abobrinha-de-moi ta cv. Caserta, na Fazenda Lagoa Bonita, município de Artur Nogueira, SP, de propriedade do Instituto Adventista de Ensino (IAE).

o primeiro ensaio foi instalado em uma área cultivada com cerca de $60 \mathrm{~m}$ de comprimento por $24 \mathrm{~m}$ de larguㅡ ra. Esse campo foi dividido transversalmente em duas metades. Cada uma dessas metades foi dividida em 3 parcelas de 6 linhas onde foram sorteados os tratamentos que foram: aplica ção de casca de arroz em faixas de 60 e $120 \mathrm{~cm}$, o que correspondeu à cokertura cio solo em 50 e $100 \%$ respectivamente com esse produto. As tes Eëmunhas não receleram a casca de arroz. O mesmo procelimento foi fei 
to com a outra metade. O espaçamento de plantio da abobrinhade-moita cv. Caserta, foi de 1,20 x 0,60 m na linha, deixando se apenas 1 planta por cova. Os tratos culturais aplicados à cultura foram os normalmente feito pelo produtor. Como bordaduras deixou-se 1 linha nas partes superior e inferior do cam po e 2 covas nas laterais dos tratamentos. Semanalmente fezse uma pequena cobertura suplementar de casca de arroz.

o plantio da cultura foi feito em 30/04/87 e protocolos semanais foram realizados de $11 / 05$ a 08/06/87, quan do então passaram a ser feitos a cada duas semanas, até 07/87. Os protocolos foram realizados anotando-se o número total de plantas de cada linha e o das que apresentavam sinto mas de mosaico. A análise dos resultados foi feita apenas com os dados das 4 linhas centrais de cada parcela, desprezando se as linhas externas.

No segundo experimento (Figura 2), conduzido no mesmo local, utilizou-se o mesmo espaçamento, de 1,20 x 0,60m e uma planta por cova. O delineamento experimental foi o de blocos ao acaso com 4 tratamentos e 8 repetições. Os tratamentos consistiam em aplicação de faixas de casca de arroz de 30,60 e $120 \mathrm{~cm}$, ao longo das linhas de plantio. As testermunhas não receberam a casca de arroz. Isto representou a cobertura de 0,25,50 e 100\%. do solo com a casca de arroz. As parcelas experimentais foram representadas por canteiros de 10 plantas. Cada parcela era separada uma da outra por uma distância de cerca de 1,80 m na linha e 1,20 m entre linhas. 


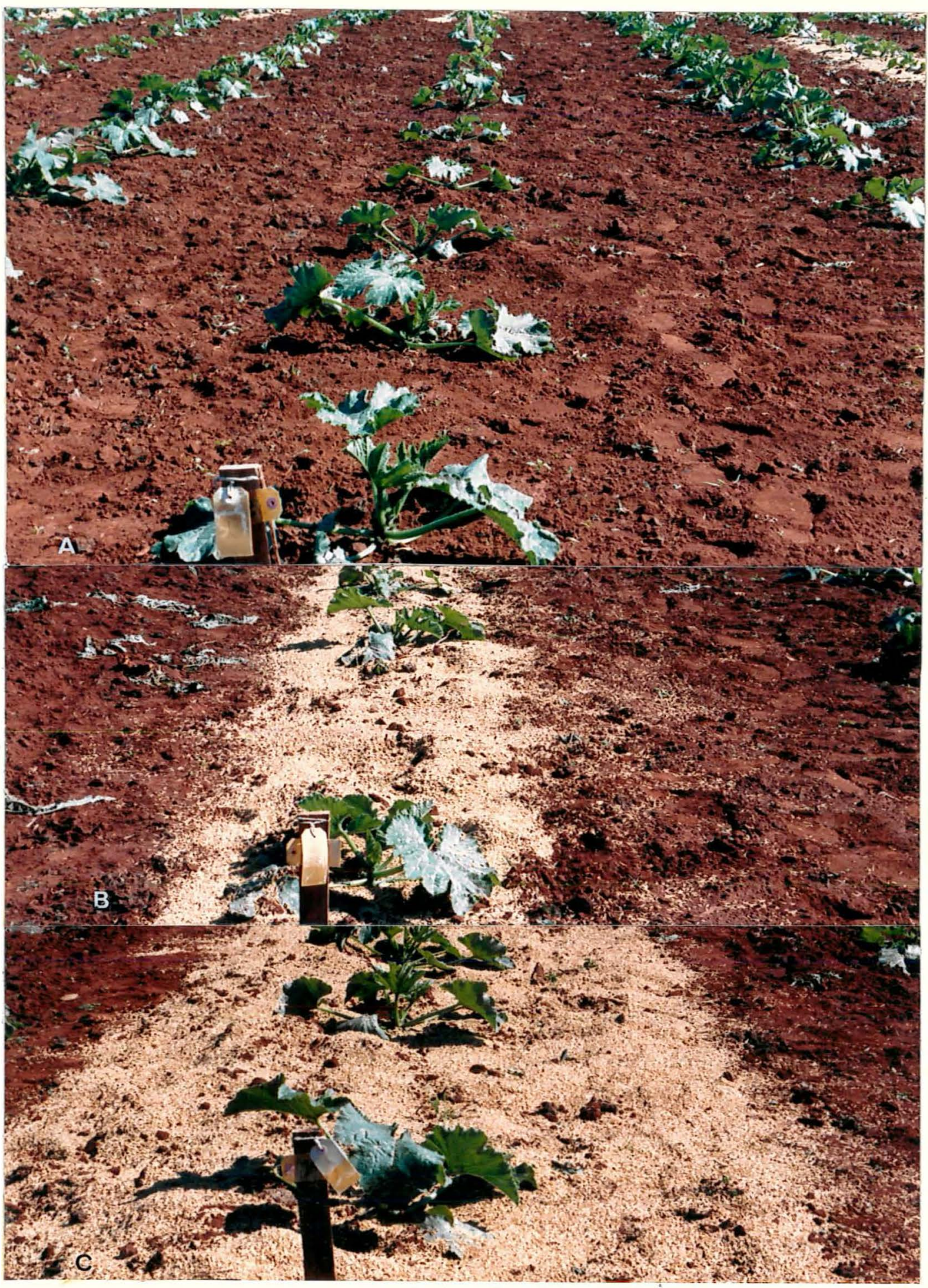

Figura 2. Ensaio de campo com diferentes faixas da superfície refle ctiva de casca de arroz. A - Vista geral do campo. B = Faixa de $60 \mathrm{~cm}$. C - Faixa de $120 \mathrm{~cm}$. 
O plantio foi feito em 20/06/88. Os tratos cul turais aplicados ao experimento foram os normalmente feitos pe lo produtor. Semanalmente fazia-se uma pequena cobertura suplementar de casca de arroz.

Foram feitos protocolos semanais, a partir de 20/07, determinando-se o número total de plantas e o daquelas afetadas, por parcela. Foram feitas análises de variância das médias porcentuais de infecção para as datas em que as diferenças foram mais evidentes. A produção de frutos comerciais, em peso, de cada parcela, também foi medida. 


\section{RESULTADOS E DISCUSSÃO}

4.I. Flutuação populacional das espécies de afídeos 4.1.1. Total anual das espécies mais frequentemente coletadas

O número total de indivíduos dos 5 grupos de afídeos alados coletados na armadilha de sucção, em cada um dos anos de 1984 a 1988, estão apresentados na Tabela 1 .

Uma análise dos resultados mostra que a composição da população mais abundante é constituída de um número relativamente pequeno de espécies. Somente as espécies do gênero Aphis, contribuíram com 47,1\% do total, seguidas de Schizaphis graminum $(20,5 \%)$, Rhopalosiphum spp. $(6,9 \%)$ e Myzus persicae $(6,5 \%)$. Portanto, todas essas espécies juntas representam 81\% do total capturado. A quantidade total de afi deos coletados nesses 5 anos de coleta ininterrupta foi de 22.660 individuos.

O número de indivíduos alados do grupo Aphis, variou de 1.637 em 1985 a 2.698 em 1988. O número captura- 
Tabela 1. Número total anual de alados de afídeos coletados em arma ilha de sucção, das espëcies mais co muns, durante os anos de 1984 a 1988, no Centro Experimental de Campinas.

\begin{tabular}{|c|c|c|c|c|c|c|c|c|c|c|c|c|}
\hline \multirow{2}{*}{ Espëcies } & \multicolumn{12}{|c|}{$\begin{array}{l}\text { Total de alados (no) de espécies de afícleos coletados em cada um dos anos indicados } \\
\text { e respectivas porcentagens (\%), total coletado nos } 5 \text { anos e porcentagem de cada es- } \\
\text { pécie em estudo e total das espécies coletadas. }\end{array}$} \\
\hline & no & $\%$ & n! & $\%$ & $n ?$ & $\%$ & nọ & $\%$ & n! & $\%$ & n! & $\%$ \\
\hline M. persicae & 323 & 5,6 & 478 & 12,6 & 289 & 7,2 & 190 & 4,8 & 184 & 3,5 & 1464 & 6,5 \\
\hline Rhopalosiphum spp. & 330 & 5,7 & 269 & 7,1 & 262 & 6,6 & 319 & 8,1 & 381 & 7,3 & 1561 & 6,9 \\
\hline S. graminum & 1700 & 29,7 & 591 & 15,6 & 645 & 16,2 & 793 & 20,1 & 922 & 17,7 & 4651 & 20,5 \\
\hline
\end{tabular}


do em 1984 foi comparável ao de 1988, enquanto que dos três anos restantes, ou seja, de 1985 a 1987, foram inferiores e também comparáveis entre si. Estes resultados mostram que há anos mais e menos favoráveis às revoadas. Isto pode represen tar anos de maiores ou menores incidências do vírus transmiti dos por este grupo de espécies. Segundo COSTA (1972a) dentro deste gênero as espécies, A. gossypii, A. craccivora e A. spe raecola, são as mais abundantes em Campinas, SP, local onde foi conduzido o presente experimento. A importância deste fa to é de que essas três espécies são consideradas vetoras do VMM-Me (ADLERZ, 1974 e SAKO et alii, 1977).

A espécie M. persical apresentou uma população coletada na armadilha de sucção que variou de 184 no ano de 1988 a 478 em 1985. Portanto bem inferior ao total do gru po acima. Essa espécie, juntamente com as espécies do gênero Aphis, são consideradas as mais eficientes vetoras do VMM-Me e de grande importância na epidemiologia (ADLERZ \& EVE RETT, 1968; ADLERZ, 1974; SAKO et alii, 1977). Como será vis to mais adiante, a importância do gênero Aphis na epidemiologia foi confirmada, mas não para M. persicae.

Das espécies estudadas individualmente, $S$. gra minum foi a mais populosa. O número de indivíduos coletados nos 5 anos variou de 591 no ano de 1985 a 1.700 em 1984.

O grupo das espécies de Rhopalosiphum apresen tou uma população alada coletada na armadilha de 262 indivíduos em 1986 a 381 em 1988. Este gênero é representado qua- 
se na sua totalidade por 3 espécies, $R$. maidis (Fitch.), $R$. rufiabdominalis (Sasaki) e R. padi (L.). A espécie F. rufiab dominalis foi encontrada colonizando raizes de abobrinha-demoita cv. Caserta, em campo (YUKI \& COSTA, 1989a). Mostrouse capaz de transmitir o VMM-Me, embora com baixa eficiência (YUKI \& COSTA, 1989b). Esses autores acham que epidemiologicamente a importância desta espécie é pequena.

No grupo denominado outras espécies, que inclui todas as outras espécies não analisadas aqui, foram capturados de 806 indivíduos em 1984 e 1.024 em 1988. Dado o grande número de espécies distribuídas neste grupo, o nümero com que cada uma delas contribui se torna tão pequeno que epidemiologicamente perde a importância.

Nos estudos feitos por COSTA \& COSTA (1972b), quando realizaram coleta de afídeos no período de 1967 a 1971 em armadilha amarela de água, em Campinas, no mesmo local do presente experimento, as proporções entre as espécies praticamente não coincidiram com as das coletas aqui descritas. Es te fato se deve basicamente à seguinte razão: houve diferença nas armadilhas utilizadas, a de CosTA \& COSTA (1972a) foi a amarela de água, que atua de forma atrativa. A utilizada no presente experimento foi a armadilha de sucção, que não tem atratividade, apenas succionando um determinado volume de ar que passa sobre a sua superfície. Como se sabe que exis tem diferenças na sensibilidade às cores pelos afídeos (MOERI CKE, 1957 e COSTA, 1972b), realmente os números de insetos co 
letados e as proporções entre espécies deveriam ser diferen tes. Este fato já era previsto em razão do conhecimento do estudo feito por costa (1970), quando determinou a variação sazonal do M. persicae através da coleta em armadilhas de água e de sucção. A proporção coletada na armadilha de sucção foi em torno de $15 \%$ da de água, considerando sempre o mesmo período. Entretanto, as curvas que representam as variações na população coletada nos dois tipos de armadilhas apresentam: a mesma configuração. A armadilha de sucção è um aparelho de captura de afídeos mais preciso, pois, ela amostra a população real de alados em vôo, num determinado volume de ar (TAY LOR, 1962). Portanto, o número de indivíduos de cada espécie coletada na armadilha de sucção representa a proporção com que cada uma delas contribui. Com isso a importância de cada espécie ou gênero na epidemiologia da moléstia poderá ser deter minada com mais precisão.

\subsubsection{Flutuação mensal no período de janeiro de}

\section{4 a dezembro de 1988}

A flutuação populacional mensal das espécies mais comuns de afídeos coletados na armadilha de sucção, ou seja, Aphis spp., M. persicae, Rhopalosiphum spp., S. graminum, a lém da soma das outras espécies e a soma total, em cada um dos anos de 1984 a 1988, podem ser vistas nas Tabelas 2 a 6 . 
Tabela 2. Flutuação populacional mensal das espécies mais comuns de afídeos e total das espécies coletadas, durante o ano de 1984.

Quantidade de afídeos alados, em revoada, coletados em armadilha de sucção das espécies ou grupo de espécies e nos meses abaixo mencionados.

Meses

\begin{tabular}{|c|c|c|c|c|}
\hline $\begin{array}{l}\text { Aphis } \\
\text { spp. }\end{array}$ & $\begin{array}{l}\text { Myzus } \\
\text { persicae }\end{array}$ & $\begin{array}{l}\text { Rhopalosi } \\
\text { phum spp. }\end{array}$ & $\begin{array}{c}\text { Schiza- } \\
\text { phis gra- } \\
\text { minum }\end{array}$ & $\begin{array}{l}\text { Outras } \\
\text { espëcies }\end{array}$ \\
\hline
\end{tabular}

\begin{tabular}{lrrrrrl} 
Janeiro & 54 & 5 & 31 & 18 & 22 & 130 \\
Fevereiro & 334 & 15 & 19 & 491 & 52 & 911 \\
Março & 172 & 21 & 9 & 373 & 26 & 601 \\
Abril & 505 & 27 & 55 & 248 & 60 & 895 \\
Maio & 152 & 63 & 51 & 182 & 39 & 487 \\
Junho & 51 & 31 & 20 & 127 & 51 & 280 \\
Julho & 47 & 20 & 14 & 43 & 73 & 197 \\
Agosto & 40 & 9 & 19 & 8 & 57 & 133 \\
Setembro & 153 & 52 & 42 & 51 & 119 & 417 \\
Outubro & 258 & 62 & 23 & 33 & 168 & 544 \\
Novembro & 214 & 5 & 6 & 19 & 56 & 300 \\
Dezembro & 592 & 13 & 41 & 107 & 85 & 836 \\
Total & 2572 & 323 & 330 & 1700 & 806 & 5731 \\
\hline
\end{tabular}


Tabela 3. Flutuação populacional mensal das espécies mais comuns de afideos e total das espécies coletadas, durante o ano de 1985.

\begin{tabular}{|c|c|c|c|c|c|c|}
\hline \multirow{2}{*}{ Meses } & \multicolumn{6}{|c|}{$\begin{array}{l}\text { Quantidade de afídeos alados, em revoada, coletados em arma- } \\
\text { dilha de sucção das espécies ou grupos de espécies e nos me- } \\
\text { ses abaixo mencionados. }\end{array}$} \\
\hline & $\begin{array}{l}\text { Aphis } \\
\text { spp. }\end{array}$ & $\begin{array}{c}\text { Muzus } \\
\text { persicae }\end{array}$ & $\begin{array}{l}\text { Rhopalosi } \\
\text { phum spp. }\end{array}$ & $\begin{array}{l}\text { Schiza } \\
\text { phis gra } \\
\text { minum }\end{array}$ & $\begin{array}{l}\text { Outras } \\
\text { espécies }\end{array}$ & Total \\
\hline Janeiro & 132 & 47 & 32 & 215 & 75 & 501 \\
\hline Fevereiro & 26 & 16 & 9 & 147 & 36 & 234 \\
\hline Março & 129 & 22 & 32 & 20 & 38 & 241 \\
\hline Abril & 66 & 25 & 20 & 16 & 54 & 181 \\
\hline Maio & 366 & 104 & 55 & 82 & 145 & 752 \\
\hline Junho & 295 & $154 x$ & 55 & 63 & 173 & 740 \\
\hline Julho & 69 & $71 * *$ & 25 & 28 & 51 & 244 \\
\hline Agosto & 21 & 4 & 6 & 5 & 69 & 105 \\
\hline Setembro & 28 & 21 & 13 & 9 & 54 & 125 \\
\hline Outubro & 31 & 9 & 6 & 1 & 51 & 98 \\
\hline Novembro & 22 & 2 & 3 & 2 & 31 & 60 \\
\hline Dezembro & 452 & 3 & 13 & 3 & 36 & 507 \\
\hline TOTAL & 1637 & 478 & 269 & 591 & 813 & 3788 \\
\hline
\end{tabular}

* Coletado 1 macho da espécie.

$*$ Coletados 2 machos da espécie. 
Tabela 4. Flutuação populacional mensal das espécies mais comuns de afídeos e total das espécies coletadas, durante o ano de 1986.

Quantidade de afídeos alados, em revoada, coletados em armadi hha de sucção das espēcies ou grupo de espécies e nos meses abaixo mencionados.

Meses

Aphis Muzus Rhopalosi Schiza- Outras
spp. persicae phum spp. phis gra- espécies

\begin{tabular}{lrrrrrr} 
Janeiro & 206 & 5 & 37 & 19 & 21 & 288 \\
Fevereiro & 30 & 5 & 18 & 44 & 16 & 113 \\
Março & 39 & 3 & 17 & 16 & 42 & 117 \\
Abril & 29 & 9 & 32 & 10 & 43 & 123 \\
Maio & 18 & 4 & 7 & 2 & 20 & 51 \\
Junho & 134 & 39 & 40 & 138 & 147 & 498 \\
Julho & 176 & 90 & 39 & 122 & 181 & 608 \\
Agosto & 31 & 9 & 8 & 8 & 42 & 98 \\
Setembro & 37 & 8 & 10 & 16 & 83 & 154 \\
Outubro & 30 & 88 & 7 & 19 & 134 & 278 \\
Novembro & 144 & 18 & 18 & 158 & 85 & 423 \\
Dezembro & 1053 & 11 & 29 & 93 & 50 & 1236 \\
Total & 1927 & 289 & 262 & 645 & 864 & 3987 \\
\hline
\end{tabular}


Tabela 5. Flutuação populacional mensal das espécies mais comuns de afídeos e total das espécies coletadas, durante o ano de 1987.

Quantidade de afídeos alados, em revoada, coletados em armadilha de sucção das espécies ou grupo de espécies e nos meses abaixo mencionados.

Meses

Aphis Myzus Rhapalosi Schiza outras total
spp. persical phum spp.
minum espécies

Janeiro

31

4

34

26

26

121

Fevereiro

51

6

14

21

21

113

Março

78

9

21

9

63

180

Abril

209

14

36

92

68

419

Maio

119

13

38

175

68

413

Junho

51

16

32

11

57

167

Julho

125

62

41

92

350

Agosto

53

24

18

88

189

Setembro

28

9

9

62

148

Outubro

84

13

9

286

84

476

Novemb ro

225

17

26

7

101

376

Dezembro

777

3

41

90

82

993

TOTAL

1831

190

319

793

812 
Tabela 6. Flutuação populacional mensal das espécies mais comuns de afídeos e total das espécies coletadas, durante o ano de 1988.

Quantidade de afídeos alados, em revoada, coletados em armadilha de sucção das espécies ou grupo de espécies e nos meses abaixo mencionados.

Meses

Aphis Myzus Rhopalosi Shiza Outras

spp. persicae phum spp. phis grami espécies

\begin{tabular}{|c|c|c|c|c|c|c|}
\hline Janeiro & 64 & 7 & 44 & 213 & 39 & 367 \\
\hline Fevereiro & 120 & 6 & 22 & 88 & 40 & 276 \\
\hline Março & 218 & 9 & 40 & 97 & 72 & 436 \\
\hline Abril & 183 & 19 & 47 & 80 & 99 & 428 \\
\hline Maio & 264 & 26 & 48 & 94 & 98 & 530 \\
\hline Junho & 50 & 11 & 47 & 162 & 97 & 367 \\
\hline Julho & 59 & 34 & 31 & 144 & 111 & 379 \\
\hline Agosto & 109 & 35 & 19 & 24 & 151 & 338 \\
\hline Setembro & 57 & 11 & 7 & 5 & 58 & 138 \\
\hline Outubro & 33 & 10 & 7 & 0 & 35 & 85 \\
\hline Novembro & 96 & 6 & 15 & 2 & 60 & 179 \\
\hline Dezembro & 1445 & 10 & 54 & 13 & 164 & 1686 \\
\hline TOTAL & 2698 & 184 & 381 & 922 & 1024 & 5209 \\
\hline
\end{tabular}


Em 1984, verificaram-se períodos de revoadas mais densas de Aphis spp., nos meses de fevereiro a abril e de outubro a dezembro, com o pico em dezembro. Foram coletados nes tes meses $80,7 \%$ do total anual. M. persicae apresentou períodos de revoadas mais densas de abril a junho e de setembro a outubro, coletando-se $72,7 \%$ do total anual nesses 5 meses. o pico foi observado em maio, apesar, de o pico de outubro ser equivalente. Rhopalosiphum spp. apresentou períodos de revoa das em janeiro, abril a maio, setembro e dezembro, coletandose $66,7 \%$ do total, e observando-se o pico populacional em abril. S. graminum apresentou período de revoadas bem distin to de fevereiro a maio, coletando nesse período $76,1 \%$ do total. O pico populacional foi observado em fevereiro. Uma ten dência de elevação na população foi observada em dezembro.

No ano de 1985, as espécies de Aphis apresenta ram maiores revoadas em janeiro, março, maio, junho e o pico em dezembro, coincidindo: com o ano anterior. Coletou-se nes ses períodos $83,9 \%$ do total anual. M. persicae apresentou maio res revoadas de maio a julho, com o pico em junho, coletandose nesse período $68,8 \%$ do total. Uma elevação na população, não muito pronunciada, foi observada em janeiro. Esta revoada deve corresponder ao observado por CosTA \& COSTA (1972b), que, ocasionalmente, em anos de verão mais ameno, verificaram revoadas maiores do que as normais em dezembiro. Em relação ainda a esta espécie, foram coletados 1 macho em junho e 2 em julho. Machos desta espécie já haviam sido relatado an- 
teriormente por COSTA (1969b), e ocorreram de forma eventual. Em virtude da ocorrência das formas vivíparas partenogenéticas durante todo o ano, essas formas sexuadas não apresentam importância epidemiológica, mesmo que venha a se observar o ciclo sexuado. Rhopalosiphum spp. apresentou revoadas mais densas nos meses de janeiro e de março a julho, sendo coletado nesses meses $81,4 \%$ do total. Em maio e junho foram coleta dos maiores números deste grupo de afídeos. S. graminum, cuja população coletada foi baixa neste ano, apresentou revoadas maiores em janeiro, fevereiro, maio e junho, coletandose $85,8 \%$ do total. O grupo formado pelas outras espécies apresentou re voadas mais densas nos meses de maio e junho, sendo coletados nesses meses $39,1 \%$ do total. O restante foi distribuído de forma relativamente equitativa nos outros meses.

Em 1986, Aphis spp. apresentaram revoadas maio res nos meses de janeiro, junho, julho, novembro e um pico mui to pronunciado em dezembro. Foram coletados nesses meses $88,9 \%$ do total e somente no mês de dezembro 54,6\%. Para M. persicae os meses de junho, julho e outubro, foram os de maiores revoadas sendo coletado somente nesses três meses $75,1 \%$ do total. Houve dois picos observados nos meses de julho e outú bro. Espécies de Rophalosiphum produziram revoadas mais den sas nos meses de janeiro, abril, junho, julho e dezembro, ten do sido coletado nesses meses 55,3\% do total desse ano. S.gra minum produziu maiores revoadas nos meses de junho, junho, no vembro e dezembro, tendo-se coletado $79,2 \%$ do total anual só nesses meses. 
No ano de 1987, espécies de Aphis apresentaram re voadas maiores nos meses de abril, maio, julho, novembro e de zembro. A coleta nesses meses foi de 79,5\% do total anual. Como nos outros anos o pico de revoadas ocorreu em dezembro, M. persicae apresentou sua maior revoada em julho. Nos outros meses do ano houve apenas pequenas revoadas. Espécies de Rho phalosiphum apresentaram revoadas maiores nos meses de janeiro, abril a julho e dezembro. Nesses meses foram coletados $69,6 \%$ do total. S. graminum apresentou periodos maiores de revoadas nos meses de abril, maio, outubro (pico) e dezembro, sendo coletados $81,8 \%$ do total nesses 4 meses.

No último ano de estudo da flutuação populacional, em 1988, espécies de Aphis apresentaram periodos maiores de revoadas de fevereiro a maio e em dezembro, tendo-se coletado $82,6 \%$ do total nesses 5 meses. Como em 1986, a quantida de coletada em dezembro, quando se verificou o pico populacio nal, foi extremamente alta, coletando-se somente neste mês 53,5\% do total anual. Em relação a M. persicae, embora revoadas acima da média tenham sido observadas em abril, maio, julho e agosto, praticamente não se destacaram dos demais meses. Com Rhopalosiphum spp., também se observou uma distribuição relativamente uniforme das revoadas, destacando-se o período de agosto a novembro pelas menores coletas e os outros 8 meses restantes com uma distribuição relativamente equitativa. S. graminum destacou-se por um período relativamente longo e contínuo de revoadas, de janeiro a julho, coletando-se nes- 
se período a quase totalidade $(95,2 \%)$ dessa espécie. A partir de agosto a população em revoadas reduziu-se.

Na Figura 3, podem ser vistas as curvas de revoadas, média dos 5 anos (1984 a 1988), de espécies ou grupos de espécies em estudo. Dois picos de revoadas podem ser vistos em relação ao total das espécies, um entre abril a julno e o outro em dezembro. Como se pode observar o pico de lisembro é extremamente alto, tendo-se coletado somente neste mês 32,4\% do total. A curva da flutuação populacional do Aphis spp., o grupo de espécies coletados em maiores quantida des na armadilha de sucção, é bastante semelhante à curva do total dos afídeos, em razão da alta proporção com que elas participam na soma total das espécies. Os picos de revoadas foram observados nos meses de maio, junho e dezembro, o que praticamente coincide com os de cosTA \& CosTA (1972b) que verificaram picos de revoadas entre abril e junho e em dezembro, no período de 1967 a 1971 . O maior pico de revoadas em abril, observado por esses autores deveu-se a uma revoada excepcional de A. gossypii nesse mês, no ano de 1971 . Dos 10.382 indivíduos coletados em abril, durante os anos de 1967 a 1971, 8.913 foram coletados somente em 1971. Portanto, eliminando o ano de 1971, que pode ser considerado anormal para Aphis spp., o pico de revoadas maior coincide com os resultados aqui obtidos, que foi em dezembro. 


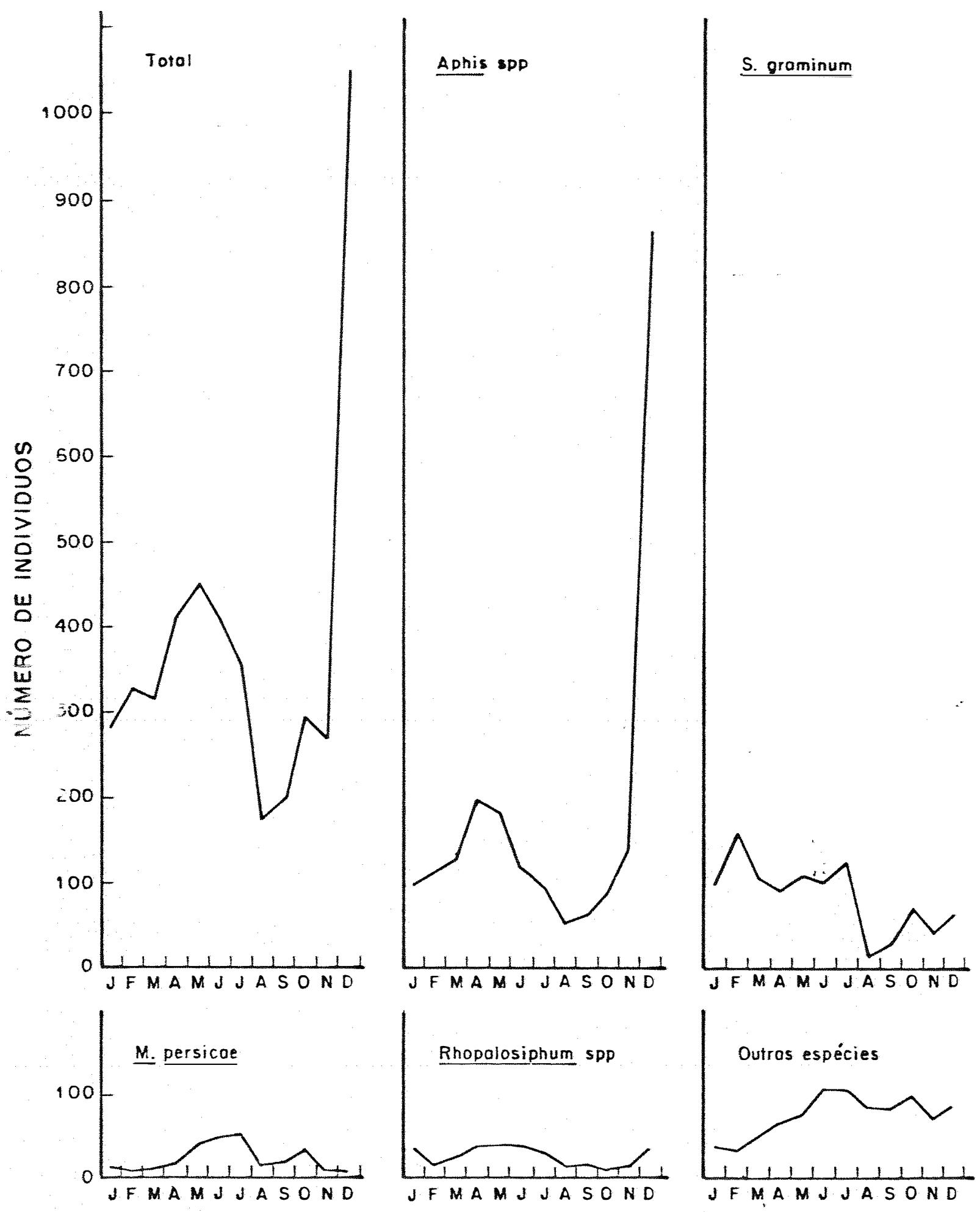

Figura 3. Flutuação populacional média, dos anos de 1984 a 1988, das espécies mais comuns de afídeos alados, coletadas am armadilhas de sucção, no Centro Experimental de Campinas. 
A espécie S. graminum apresentou revoadas cons tantes de janeiro a julho, com picos em fevereiro e em julho. Em seguida, verificou-se uma queda acentuada nas coletas, nos dois meses seguintes (agosto e setembro), subindo nos meses subsequentes, mas a níveis inferiores ao do 10 semestre. Esses resultados correspondem, em parte, aos já relatados por YUKI et alii (1980), quando verificaram que as revoadas maiores ocorriam, em Campinas, nos meses mais quentes do ano até meados do outono entretanto, não mencionaram o pico de julho. M. persicae, apresentou períodos maiores de re voadas bastante restritos, somente nos meses de maio, julho e outubro, com pico em julho. COSTA (1970) e COSTA \& COSTA (1972b) verificaram um período de revoadas de abril a agosto/setembro e excepcionalmente em dezembro, quando ocorrem temperaturas baixas nesse mês. Portanto, o período de revoadas observado por esses autores foi mais longo do que os vistos neste tra balho. Por outro lado, estes autores não observaram revoadas em outubro. No experimento aqui relatado não se observou revoada em dezembro.

As maiores revoadas das espécies Rhopalosiphum foram em janeiro, abril a julho e dezembro, mas sem nenhuma expressão. COS TA \& COSTA (1972b), verificaram ocorrer dois periodos de maior atividade de vôo para estas espécies: o primeiro de abril a junho e o outro em novembro, dezembro e janeiro, o que praticamente coincide com os resultados aqui apresentados.

Os resultados obtidos no presente experimen- 
to mostraram que a atividade dos afídeos não sofreu interrupção em nenhum mês dos 5 anos analisados. Aparentemente não existem fatores que limitam o desenvolvimento de alados ou são capazes de inibir os vôos. Apenas cada espécie apresenta um período definido em que há maiores produções de alados que saem em vôo.

Os estudos aqui realizados mostraram que há uma certa continuidade nas revoadas durante todo o ano. Ora uma ou outra espécie se encontram em revoada mais densa. Isto mostra que em qualquer época do ano há condições de disseminação da moléstia, desde que haja fontes do vírus nas proximi dades das culturas. As cucurbitáceas são recomendadas para serem plantadas no Estado de São Paulo, nas épocas maís quentes, por serem sensiveis às geadas (INSTITUTO AGRONÔMICO, 1987). Na região de Campinas, o período de maior cultivo ocorre da primavera até o outono (setembro a maio) quando então há redução no plantio. Alguns produtores de abobrinha se arriscam a produzi-la durante o inverno, mesmo correndo risco de geadas, em razão dos melhores preços que obtém nesse período. Es te fato mostra que o período de maiores cultivos de abobrinha coincide com a existência de maiores populações das espécies de Aphis e de S. graminum em revoadas. O pulgão $M$. persicae, além de população relativamente baixa, ten seu período de maiores densidades de revoadas nos meses de pouco cultivo das cucurbitáceas. 


\subsubsection{Eficiência comparativa de espécies de afídeos na transmissão do VMM-Me}

Os resultados dos testes comparativos de eficiência podem ser vistos na Tabela 7. A espécie $M$. persicae, sem dúvida alguma, foi a mais eficiente das testadas, com uma média geral, nos 15 testes de 92,3\%. Segue-se a ela A. fabal solanella, também com boa eficiência. As espécies, $S$. graminum e A. craccivora, apresentam eficiência razoáveis e A. gossypii e A. spiraecola eficiências bastante baixas. O po sicionamento das espécies testadas manteve-se o mesmo quando se considerou M. persicae com o indice 100.

A eficiência de transmissão de A. gossypii obtida no presente experimento pode ser considerada bastante baixa $(15,4 \%)$, quando comparada aos dados de outros autores. ADLERZ (1974) e SAKO et alii (1977), obtiveram uma eficiên cia de 92 e 100\% respectivamente, em seus trabalhos. A alta eficiência obtida para a espécie M. persicae, coincidiu com o trabalho de SAKO et alii (1977), que obteve 100\% de transmissão do VMM-Me, mas não com o de ADLERZ (1974), cujo resultado de transmissão foi de 69\%, inferior aó de A. gossypii (92\%) e A. spiraecola (80\%), entretanto, essa eficiência ainda pode ser considerada alta. Ainda no trabalho de ADH̃ERZ (1974) A. spiraecola foi um dos mais eficientes vetores testados, enquanto que nos resultados aqui apresentados, foi um dos menos eficientes, com apenas 13,0\%. A. craccivora apresentou tam- 
Tabela 7. Eficiência de transmissão do VMM-Me por algumas espécies de afídeos, em comparação com M. persicae.

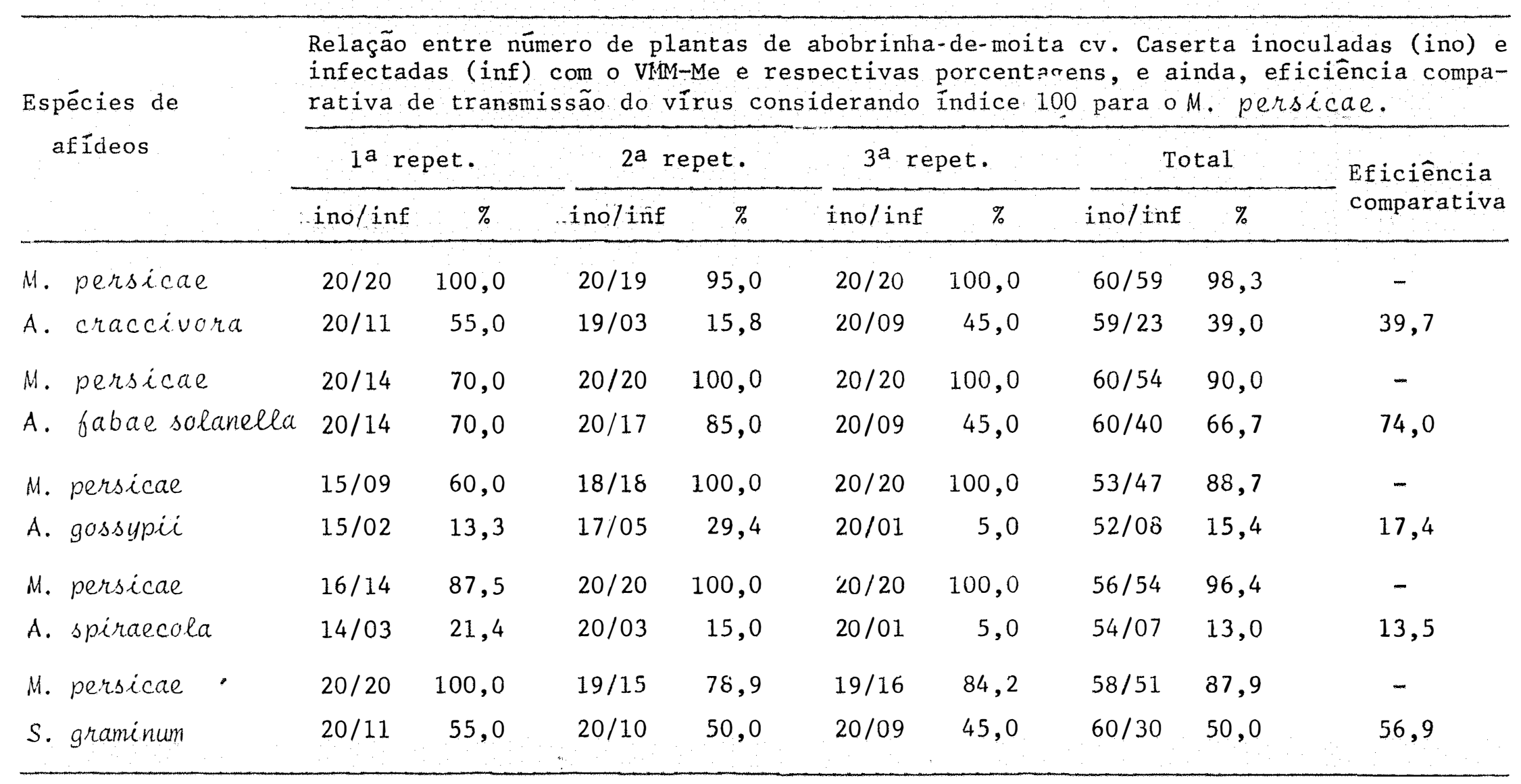


bém eficiencia inferior aos resultados obtidos pelos autores acima citados. As diferenças nas eficiências de transmissão da mesma espécie de afídeo entre os trabalhos aqui discutidos e os resultados apresentados, se devem provavelmente às raças ov biótipos diferentes utilizados nos respectivos testes.

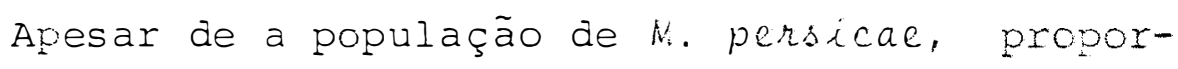
cionalmente em relação às outras espécies de afíäeos ter siajo baixa, a alta eficiência de transmissão Eväria compensar esse menor número de alados. Por outro lado, as espécies de Aphis, que compõe quase metade do nümero total coletado na ar madilna de sucção, apesar de ter eficiência injerior, poàe ser compensada pela maior proporção con que contribui no total. A espécie S. graminum parece apresentar importäncia maion do que se esperava em razão da população relativamente alta, contribuindo com $20,5 \%$ do total e possuindo razoável eficiência de transmissão do VMM-Me. As espécies de Rhopalosiphum a parentemente não apresentam importância devido à baixa popula ção e aparente ineficiēncia na transmissão.

Das espécies em estudo, além de $R$. rúoiabdom nalis, as espécies A. gossypil e M. persicue podem colonizar as cucurbitáceas (BLACKMAN \& EASTOP, 1984). Todas elas são vetoras do VMM-Me em maior ou menor eficiência. Eventualmente poderiam ter importância na epiaemiologia se estiverem coloni zando cucurbitáceas próximos às culturas de abobrinina-de-moita. Embora tenina-se encontrado, no campo, àpenas coiónias de R. rufiabduminalis em culturas de abobrinha-de-moita, as de 
abóbora, que praticamente não recebem inseticidas, devem servir de boas fontes tanto do virus como dos vetores que podem disseminar o vírus para outras culturas ou mesmo dentro da cultura. No caso da abobrinha de moita, que recebe melhores cuidados fitossanitários, a disseminação de fora para den tro deve ser a mais importante. Nessas condições ainda, a disseminação dentro pode ocorrer de alados que vem de fora para dentro, realizando vôos apetitivos, adquirindo o vírus de fontes dentro da cultura.

4.2. Correlação entre a incidência da moléstia e a flutuação populacional dos vetores

A incidência mensal do VMM-Me, dentro dos períodos de exposição apresentados, pode ser observada na Tabe1a 8. De uma maneira geral observa-se que as maiores incidên cias ocorreram do final da primavera (novembro) até meados do outono (maio), quando então se verifica uma redução na incidência que se estende durante 0 inverno. No segundo ano de exposição, de abril/85 a março/86, as incidências durante o inverno foram relativamente altas, quando comparadas com os outros anos. Em maio/86 as intensas chuvas ocorridas provoca ram erosões nos canteiros, tendo sobrado apenas 3 plantas que se mostraram sadias. 
Tabela 8. Incidência mensal do VMM-Me, em plantas testes de abobrinha-de-moita, no período de 26/03/84 a $27 / 03 / 88$.

Relação entre números de plantas expostas (ne) e que se infectaram (ni) com o ViM-Me e as respectivas porcentagens $(\%)$, nos períodos indicados.

\begin{tabular}{|c|c|c|c|c|c|c|c|c|c|c|c|c|}
\hline \multirow{2}{*}{$\begin{array}{l}\text { Nês de } \\
\text { referência }\end{array}$} & \multicolumn{3}{|c|}{$1984 / 85$} & \multicolumn{3}{|c|}{$1985 / 86$} & \multicolumn{3}{|c|}{$1986 / 87$} & \multicolumn{3}{|c|}{$1987 / 88$} \\
\hline & $\begin{array}{l}\text { Período de } \\
\text { exposição }\end{array}$ & $\mathrm{ne} / \mathrm{ni}$ & $\%$ & $\begin{array}{l}\text { Perícob de } \\
\text { exposição }\end{array}$ & $\mathrm{ne} / \mathrm{ni}$ & $\%$ & $\begin{array}{l}\text { Perícob de } \\
\text { exposição }\end{array}$ & $n e / n i$ & $\%$ & $\begin{array}{l}\text { Perícodo de } \\
\text { exposicãa }\end{array}$ & $n e / n i$ & $\%$ \\
\hline Abril & $26 / 03-26 / 04$ & $44 / 28$ & 63,6 & $28 / 03-28 / 04$ & $27 / 10$ & 37,0 & $26 / 03-27 / 04$ & $28 / 20$ & 71,4 & $30 / 03-27 / 04$ & $34 / 32$ & 94,1 \\
\hline Maio & $27 / 04-27 / 05$ & $54 / 31$ & 57,4 & $29 / 04-26 / 05$ & $17 / 6$ & 35,3 & $28 / 04-27 / 05$ & $3 / 0$ & 0,0 & $28 / 04-28 / 05$ & $58 / 29$ & 50,0 \\
\hline Jurho & $28 / 05-26 / 06$ & $56 / 14$ & 25,0 & $27 / 05-27 / 06$ & $28 / 21$ & 75,0 & $28 / 05-30 / 06$ & $18 / 2$ & 11,1 & $29 / 05-28 / 06$ & $60 / 2$ & 3,3 \\
\hline Julho & $27 / 06-26 / 07$ & $59 / 3$ & 5,1 & $28 / 06-28 / 07$ & $56 / 16$ & 28,6 & $01 / 06-27 / 07$ & $33 / 11$ & 33,3 & $29 / 06-28 / 07$ & $57 / 9$ & 15,8 \\
\hline Agosto & $27 / 07-28 / 08$ & $37 / 3$ & 8,1 & $29 / 07-27 / 08$ & $57 / 25$ & 43,9 & $28 / 07-26 / 08$ & $59 / 12$ & 20,3 & $29 / 07-27 / 08$ & $53 / 0$ & 0,0 \\
\hline Seterbro & $29 / 08-26 / 09$ & $34 / 0$ & 0,0 & $28 / 08-26 / 09$ & $48 / 19$ & 39,6 & $27 / 08-28 / 09$ & $59 / 6$ & 10,2 & २८/०8-27/09 & $46 / 8$ & 17,4 \\
\hline artutoro & $27 / 09-28 / 10$ & $57 / 5$ & 8,8 & $27 / 00-29 / 10$ & $62 / 25$ & 40,3 & $20 / 90-28 / 10$ & $53 / 24$ & 45,3 & $28 / 00-27 / 10$ & $31 / 20$ & 64,5 \\
\hline Noventbro & $29 / 10-27 / 11$ & $58 / 27$ & 46,5 & $30 / 10-27 / 11$ & $58 / 17$ & 29,3 & $29 / 10-27 / 11$ & $62 / 36$ & 58,1 & $28 / 10-26 / 11$ & $52 / 37$ & 71,1 \\
\hline Deserthro & $28 / 11-27 / 12$ & $52 / 52$ & $1 \infty 0,0$ & $28 / 11-26 / 12$ & $52 / 31$ & 59,6 & $28 / 11-28 / 12$ & $34 / 26$ & 76,5 & $27 / 11-27 / 12$ & $56 / 43$ & 76,8 \\
\hline Janeiro & $28 / 12-27 / 01$ & $42 / 40$ & 95,2 & $27 / 12-26 / 01$ & $48 / 46$ & 95,8 & $29 / 12-27 / 01$ & $13 / 10$ & 76,9 & $28 / 12-27 / 01$ & $52 / 45$ & 86,5 \\
\hline Fevereiro & $28 / 01-27 / 02$ & $26 / 25$ & 96,1 & $27 / 01-27 / \infty 2$ & $43 / 37$ & 86,0 & $28 / 01-26 / 02$ & $36 / 12$ & 33,3 & $28 / 01-27 / \infty 2$ & $36 / 12$ & 33,3 \\
\hline Marco & $28 / 0 Q-27 / 03$ & $36 / 31$ & 86,1 & $28 / œ R-25 / œ 3$ & $52 / 47$ & 90,4 & $27 / C 2-29 / 103$ & $53 / 28$ & 52,8 & $28 / \subseteq R-27 / \infty \Theta$ & $58 / 14$ & 24,1 \\
\hline
\end{tabular}


A flutuação populacional mensal das espécies de Aphis, M. persicae, S. graminum e de Rhopalosiphum, em com paração com as incidências mensais do vírus podem ser vistas na Figura 4. Dessas espécies, o grupo de Aphis spp. e S. graminum foram os que apresentaram as melhores correlações gráficas, pois, os períodos de maiores revoadas coincidiram com os de maiores incidência do vírus; durante o período de maiores incidências, a uma coleta de Aphis spp., correspondeu a um aumento na coleta do S. graminum e vice-versa. Ao contrārio do esperado, a curva de revoada de M. persicae, a mais eficiente vetora das espécies estudadas, não apresentou correlação com a incidência do vírus. Espécies de Rhopalosiphum tambēm não apresentaram correlação.

S. graminum não tem sido considerado de importância na epidemiologia do VMM-Me pela maioria dos investigadores. Entretanto, a coincidência dos períodos de maiores densidades de revoadas com os de maiores incidências do vírus, mostra que esta espécie pode ter importância na epidemio $\operatorname{logia}$

A correlação entre as espécies de afídeos e as incidências mensais do VMM-Me aqui apresentadas, não pode ser considerada como absolutamente definitiva. Há de se considerar que outros fatores também podem estar influindo na transmissão e disseminação do vírus. Por exemplo, a proximidade de boas fontes de inóculo é um fator interferente, pois, a presença do vetor durante todo o ano permite a disseminação do vírus para culturas próximas, mesmo no inverno. 

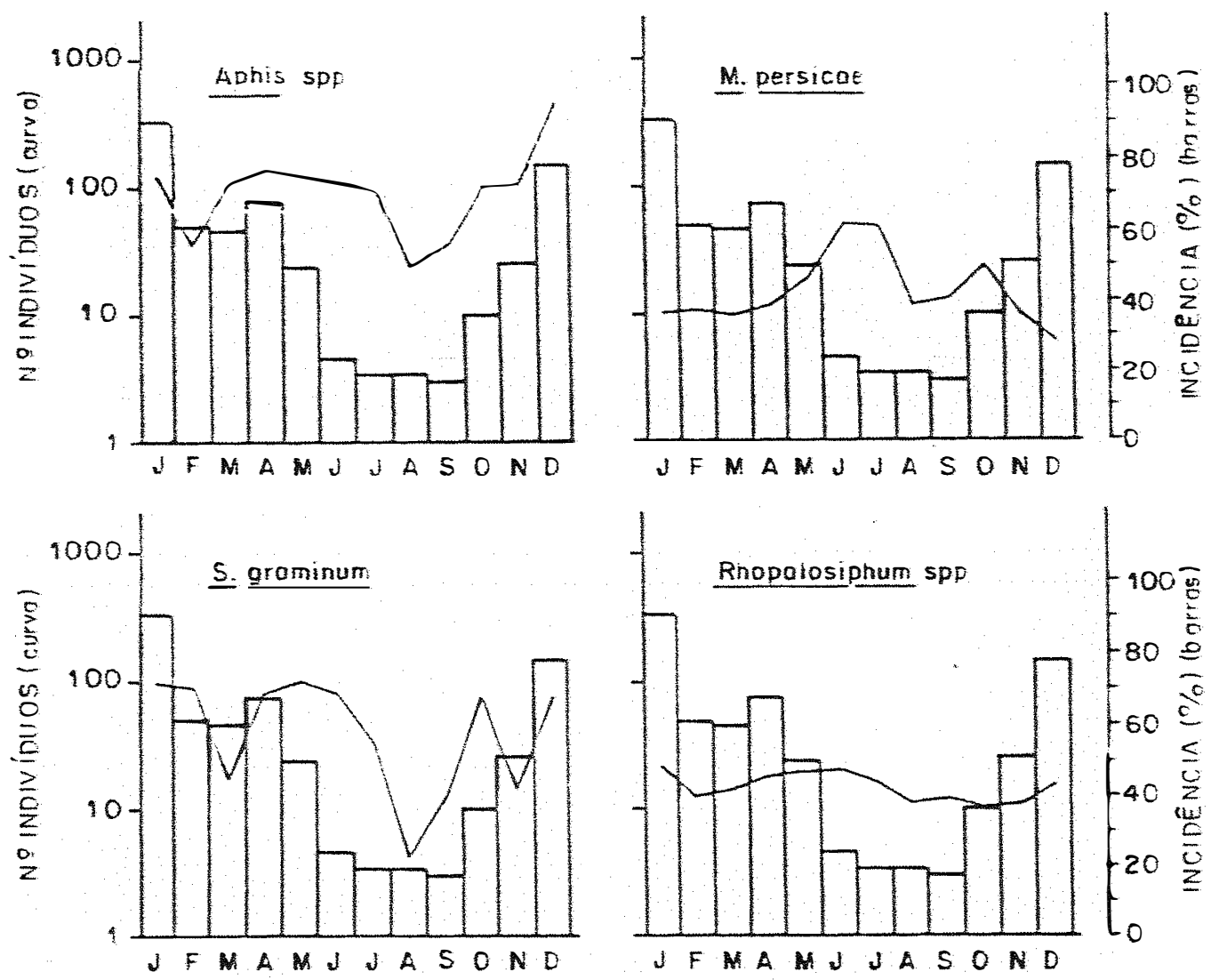

Figura 4. Incidência mensal do VMM-Me em plantas testes de abobrinha-de-moita e respectivas flutuações populacionais das espécies vetoras (média de 4 anos). 
Por fim, a importância das espécies aqui discu tidas não pode ser generalizada para outras regiões, uma vez que elas diferem climaticamente, diferindo também nas culturas e plantas da vegetação espontânea. Desse modo a proporção das espécies também se modifica, como também os períodos de maiores densidades populacionais dos vetores. Portanto, para cada região há necessidade de estudos epidemiológicos ví sando determinar a importância relativa de cada espécie ou grupo de espécies.

\subsection{Controle do VMM-Me através de medidas aplicadas contra o vetor}

\subsubsection{Testes com inseticidas e óleos}

Foram conduzidos dois experimentos visando con trolar o vetor através de inseticidas e óleos. No primeiro experimento compararam-se dois inseticidas carbamatos: 0 Aldicarb, de aplicação no solo; e o Pirimicarb, de apilicação foliar, em pulverizações. Foram feitas 17 exposições mensais consecutivas, de $28 / 11 / 74$ a $26 / 03 / 86$. No segundo experimento, avaliou-se o efeito de dois inseticidas carbamatos de aplicação no.solo, Aldicarb e Carbofuran, sōs ou em combinação com os óleos mineral (Triona B) e vegetal (Natur'oil). Fo ram feitas 20 exposições mensais consecutivas de 28/05/86 a $28 / 12 / 87$. 
ser vistos na Tabela 9 . Não foram computados os dados do 69 mês de exposição (29/04 a 26/05), devido a um intenso ataque de brocas, que matou a maioria das plantas. De uma maneira geral, a incidència do VMM-Me, foi relativamente alta em todas as exposições. Dos dois inseticidas testados, o Alaicarb apresentou efeito melhor na redução da disseminação do virus. Esse efeito foi melhor quando a pressão de inóculo foi menor. O Pirimicarb apresentou taxas de infecção comparā veis às testemunhas. Este último produto é um aficida especí fico e foi recomendado pelo Dr. H.F. van Emden ${ }^{I}$ para controIe de afídeos e consequente redução na incidência dos respectivos virus que eles transmitem. No entanto, nenhum efeito na redução do VMM-Me foi observado no presente experimento.

Aparentemente o melhor efeito do Aldicarb se deve a um melhor controle dos vetores. Por outro lado ainda, a sua ação sistêmica e persistência relativamente longa na planta, de cerca de 30 dias em plantas de batata (COsTA et alii, 1971), faz com que leve vantagem sobre o Pirimicarb que apresenta ação apenas translaminar e persistência aparentemen te menor, de alguns dias; por essa razão, mesmo com as aplica ções semanais de Pirimicarb, as brotações novas logo ficam desprotegidas, principalmente no caso da abobrinha-de-moita, cujo desenvolvimento é muito rápido.

\footnotetext{
I van Emden, H.F. ("University of Reading", Inglaterra). Comunicação pessoal, 1984 .
} 
Tabela 9. Efeito de dois inseticidas carbamatos, um de aplicação no solo e outro foliar pulverizado semanalmente, em plantas testes de abobrinha-de-moita, no controle do VMM-Me, em campo.

\begin{tabular}{|c|c|c|c|c|c|c|}
\hline \multirow[t]{3}{*}{$\begin{array}{l}\text { Períodos de } \\
\text { exposição }\end{array}$} & \multicolumn{6}{|c|}{$\begin{array}{l}\text { Rel açao entre numéro de plantas expostas (ne) e que se } \\
\text { infectaram com o vîrus e as respectivas porcentagens } \\
(\%) \text {, nas parcelas tratadas respectivamente com o Aldi } \\
\text { carb no solo e o Pirimicarb em pulverizaçoes. }\end{array}$} \\
\hline & \multicolumn{2}{|c|}{ Aldicarb } & \multicolumn{2}{|c|}{ Pirimicarb } & \multicolumn{2}{|c|}{ Testemunha } \\
\hline & $n e / n i$ & $\%$ & $\mathrm{ne} / \mathrm{ni}$ & $\%$ & $\mathrm{ne} / \mathrm{ni}$ & $\%$ \\
\hline $1928 / 11-27 / 12 / 84$ & $55 / 44 *$ & 80,0 & $51 / 43$ & 84,3 & $54 / 50$ & 92,6 \\
\hline $2028 / 12-27 / 01 / 85$ & $46 / 32$ & 69,6 & $45 / 37$ & 82,2 & $41 / 40$ & 97,6 \\
\hline $3928 / 01-27 / 02$ & $58 / 23$ & 39,6 & $21 / 15$ & 71,4 & $27 / 25$ & 92,6 \\
\hline $4928 / 02-28 / 03$ & $42 / 18$ & 42,9 & $39 / 29$ & 74,4 & $38 / 28$ & 73,7 \\
\hline $50 \quad 29 / 03-28 / 04$ & $44 / 15$ & 34,1 & $29 / 14$ & 48,3 & $26 / 10$ & 38,5 \\
\hline $6929 / 04-26 / 05$ & $-{ }^{* *}$ & - & - & - & - & - \\
\hline 79 27/05-27/06 & $48 / 25$ & 52,1 & $48 / 24$ & 50,0 & $28 / 19$ & 67,9 \\
\hline $8928 / 06-28 / 07$ & $57 / 9$ & 15,8 & $57 / 20$ & 35,1 & $56 / 14$ & 25,0 \\
\hline 90. 29./07-27/08 & $60 / 5$ & 8,3 & $58 / 24$ & 41,4 & $56 / 19$ & 33,9 \\
\hline 109 28/08-26/09 & $45 / 0$ & 0,0 & $42 / 13$ & 30,9 & $47 / 15$ & 31,9 \\
\hline $11927 / 09-29 / 10$ & $57 / 10$ & 17,5 & $59 / 24$ & 40,7 & $62 / 25$ & 40,3 \\
\hline $12030 / 10-27 / 11$ & $66 / 6$ & 9,1 & $54 / 17$ & 31,5 & $57 / 17$ & 29,8 \\
\hline $13928 / 11-27 / 12$ & $61 / 21$ & 34,4 & $61 / 26$ & 42,6 & $51 / 31$ & 60,8 \\
\hline $14928 / 12-26 / 01 / 86$ & $54 / 46$ & 85,2 & $53 / 38$ & 71,7 & $47 / 43$ & 91,5 \\
\hline $15027 / 01-27 / 02$ & $57 / 42$ & 73,7 & $58 / 38$ & 65,5 & $42 / 33$ & 78,6 \\
\hline $16028 / 02-25 / 03$ & $54 / 16$ & 29,6 & $52 / 34$ & 65,4 & $56 / 33$ & 58,9 \\
\hline 170 26/03-27/04 & $33 / 16$ & 48,5 & $7 / 6$ & 85,7 & $28 / 20$ & 71,4 \\
\hline TOTAL & $837 / 328$ & 39,2 & $734 / 402$ & 54,8 & $716 / 422$ & 58,9 \\
\hline
\end{tabular}

* Total de 3 repetições.

t* Os dados não foram considerados devido a perda quase total das plantas por infestação de brocas. 
o fato de a maioria dos trabalhos sobre o contrnle do VMM-Me, através do vetor por meio de inseticidas fos forados não terem tido sucesso, talvez tenha sido em razão de terem curto efeito residual na planta. Há inclusive relato ie aumento, embora não significativo, na disseminação do virus em parcelas pulverizadas com Demeton-S-Methyl (WYMAN et alii, 1979). O inseticida pode ter provocado uma excitação maior nos vetores, aumentando o número de vôos e disseminando o virus um pouco mais que nas testemunhas. BROADBENT (1957) já havia discutido essa idéia e a necessidade de desenvolver inseticidas que paralizassem ou matassem imediatamente os vetores para que a disseminação dos vírus não fosse maior do que se o inseticida não houvesse sido aplicado.

Embora o Aldicarb tenha reduzido a incidência do virus, essa redução não foi suficiente para que pudesse ser recomendado. O nível de controle necessita ainda ser meIhorado.

Os resultados do segundo experimento, em que se realizaram 20 exposições mensais consecutivas, a fim de se ve rificar os efeitos dos inseticidas carbamatos de aplicação no solo Aldicarb e Carbofuran, sós oú em combinação com os óleos mineral e vegetal, podem ser vistos na Tabela 10. Verifica-se que, de uma maneira geral, as incidências médias foram inferiores aos do experimento anterior. Todo o Aldicarb como Carbofuran tiveram pequeno efeito na redução da incidência do VMM-Me. Os óleos, tanto vegetal como mineral não reduziram a incidência do vírus. 
58.

Tabela 10. Efeito dos inseticidas carbamatos, Aldicarb e Carbofuran, aplicados no solo, sós ou em combinações com pulverizações de óleos vegetal ou mineral, no controle do VMM-Me, em campo.

\begin{tabular}{|c|c|c|c|c|c|c|}
\hline \multirow{3}{*}{ Tratamentos } & \multicolumn{6}{|c|}{$\begin{array}{l}\text { Relação entre número de plantas expostas (ne) e que se } \\
\text { infectaram (ni) com o VM-Me e as respectivas porcen- } \\
\text { tagens (\%), nos canteiros tratados com os óleos e in } \\
\text { seticidas abaixo citado, em três repetiçós e } 20 \text { expo } \\
\text { sições mensais consecutivas. }\end{array}$} \\
\hline & \multicolumn{2}{|c|}{$\begin{array}{c}\text { ōleo } \\
\text { vegetal -. }\end{array}$} & \multicolumn{2}{|c|}{$\begin{array}{c}\text { Ōleo } \\
\text { mineral }\end{array}$} & \multicolumn{2}{|c|}{ Testemunha } \\
\hline & $\mathrm{ne} / \mathrm{ni}$ & $\%$ & ne/ni & $\%$ & $\mathrm{ne} / \mathrm{ni}$ & $\%$ \\
\hline Aldicarb & $171 / 51$ & 29,6 & $170 / 34$ & 20,0 & $168 / 44$ & 26,2 \\
\hline Carbofuran & $164 / 40$ & 24,4 & $150 / 38$ & 25,3 & $175 / 47$ & 26,9 \\
\hline Testemunha & $167 / 77$ & 46,1 & $148 / 47$ & 31,8 & $159 / 59$ & 37,1 \\
\hline
\end{tabular}


Os dois inseticidas utilizados nesse experimen to apresentajn efeitos semelhantes, não tendo sido verifica do um melhor eteito inicial do Aldicarb, como o observado por YUKI et alii (1989) em experimento realizado em feijoeiro cv. Carioca 80 visando o controle do mosaico dourado do feijoeiro (VMDE)

Embora os óleos sejam recomendados para o controle das diversas fitoviroses transmitidas por afídeos, prin cipalmente aquelas de relação não persistente com o vetor, os resultados obtidos com cucurbitáceas não foram promissores. Mesmo aqueles que conseguiram (WYMAN et alii, 1979) con trole significativo, a alta concentração necessária para isso (4\%) causou fitoxidês e a sua produção foi semelhante à testemunha.

A ineficiência dos óleos testados inviabiliza seu uso para o controle do VMM-Me. Os inseticidas carbamatos de aplicação no solo, como já discutido anteriormente,. poderiam ser utilizados em combinação com outros métodos de controle, caso venha a ser registrado para o uso nesta cultura.

\subsubsection{Testes com substâncias reflectivas}

4.3.2.1. Efeito das purpurinas dourada e prateada

Os resultados dos experimentos em que se pulve rizou purpurinas dourada e prateada em plantas testes de abobrinha-de-moita cv. Caserta, no controle do VMM-Me, podem ser 
vistos na Tabela 11. Verifica-se que durante as 8 exposições mensais $(26 / 03 / 84$ a $28 / 10 / 84)$ as plantas tratadas com a purpurina dourada apresentaram comportamento semelhante à testemunha. O tratamento com a purpurina prateada induziu um ligeiro aumento na incidência do vírus. Lógicamente, sob essas con dições, seu uso deve ser condenado.

\subsubsection{Efeito da ãgua de cal}

Na Tabela 12 podem ser vistos os resultados dos experimentos em que se pulverizou água de cal a $10 \%$ sobre plan tas testes de abobrinha-de-moita cv. Caserta durante 20 expo sições mensais consecutivas (28/05/86 a 28/12/87). Verifica se que a incidência do VMM-Me não foi reduzida pela cal, sendo as incidências comparāveis com as das testemunhas.

Este experimento foi conduzido em razão do relativo sucesso obtido por MARCO (1986), quando pulverizou cal sobre plantas de batata e reduziu a incidência do PLRV, de re lação persistente com os afídeos vetores e do PVY, de relação não persistente; no caso do PLRV a redução da incidência medi da nos tubérculos foi de até $61 \%$ e no caso do PVY de até 68\%.

A razão pela qual as purpurinas dourada e prateada e à cal utilizadas não reduziram a disseminação do vírus do mosaico da abobrinha não foi investigada. Entretanto, algumas hipóteses podem ser formuladas. A tendência de aumento da incidência observada no experimento anterior quan- 
Tabela 11. Efeito de pulverizações com purpurinas dourada e prateada, sobre plantas testes de abobrinha-de-moita, no controle do VMMMe, em campo.

\begin{tabular}{|c|c|c|c|c|c|c|c|}
\hline \multirow{3}{*}{\multicolumn{2}{|c|}{ Períodos de }} & \multicolumn{6}{|c|}{$\begin{array}{l}\text { Relação entre número de plantas expostas (ne) e que se } \\
\text { infectaram (ni) com o vîrus e as respectivas porcen- } \\
\text { tagens }(\%) \text {, nos } 8 \text { periodos de exposiçôs. }\end{array}$} \\
\hline & & \multicolumn{2}{|c|}{$\begin{array}{l}\text { Purpurina } \\
\text { dourada }\end{array}$} & \multicolumn{2}{|c|}{$\begin{array}{l}\text { Purpurina } \\
\text { prateada }\end{array}$} & \multicolumn{2}{|c|}{ Testemunia } \\
\hline & & ne/ni & $\%$ & $n e / n i$ & $\%$ & $n e / n i$ & $\%$ \\
\hline 10 & $26 / 03-26 / 04 / 84$ & $51 / 33 *$ & 64,7 & $51 / 33$ & 64,7 & $44 / 29$ & 65,9 \\
\hline 20 & $27 / 04-29 / 05$ & $50 / 25$ & 50,0 & $57 / 44$ & 77,2 & $56 / 34$ & 60,7 \\
\hline 30 & $28 / 05-26 / 06$ & $58 / 16$ & 27,6 & $49 / 6$ & 12,2 & $58 / 14$ & 24,1 \\
\hline 40 & $27 / 06-26 / 07$ & $55 / 5$ & 9,1 & $51 / 16$ & 31,4 & $59 / 3$ & 5,1 \\
\hline 50 & $27 / 07-28 / 08$ & $35 / 5$ & 14,3 & $35 / 9$ & 25,7 & $37 / 3$ & 8,1 \\
\hline 60 & $29 / 08-25 / 09$ & $37 / 1$ & 2,7 & $41 / 1$ & 2,4 & $34 / 0$ & 0,0 \\
\hline 79 & $26 / 09-27 / 10$ & $59 / 20$ & 33,9 & $58 / 28$ & 48,3 & $60 / 7$ & 11,7 \\
\hline \multirow[t]{2}{*}{80} & $28 / 10-27 / 11$ & $58 / 19$ & 32,8 & $53 / 14$ & 26,4 & $55 / 26$ & 47,3 \\
\hline & TOTAL & $403 / 124$ & 30,8 & $395 / 151$ & 38,2 & $403 / 116$ & 28,8 \\
\hline
\end{tabular}

$\therefore$ Total de 3 repetições. 
Tabela 12. Efeito de pulverizações com água de cal em plantas testes de a bobrinha-de-moita, no controle do VMM-Me, em campo.

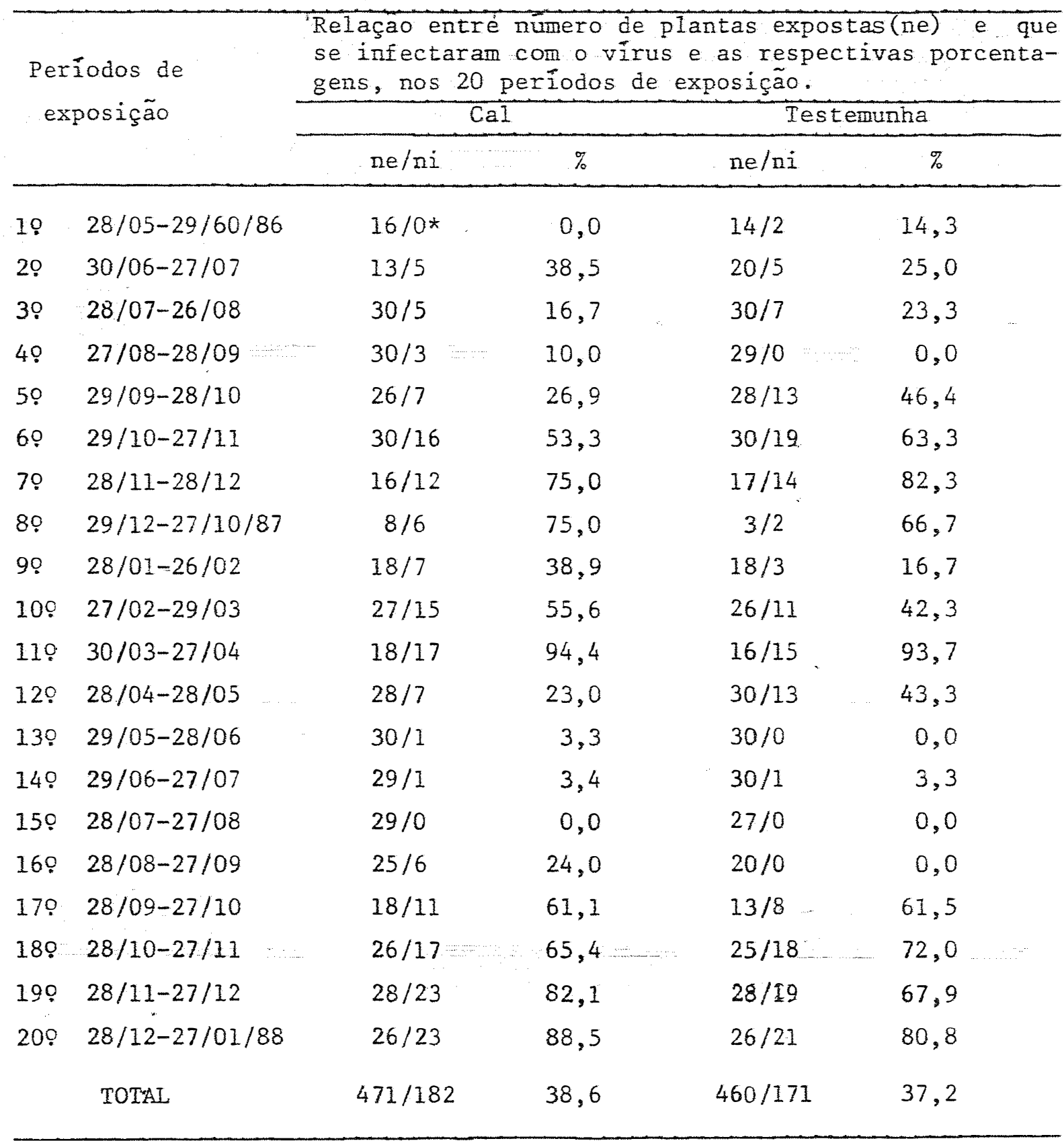

* Total de 3 repetições. 
do se utilizou purpurina prateada pode ter ocorrido em razão d: reflexão de comprimento de ondas não visiveis ao olho huma no, atrativa aos afídeos ou a algumas espécies vetoras de for ma diferencial como as observadas por COSTA. (1972b) e MARCO (1986), ou ainda, os afídeos ao descerem sobre essas superfi主 cies tornam-se excitados realizando inümeros vôos curtos aumentando a disseminação do vírus. O fato de a água de cal ter reduzido a incidência de vírus no trabalho de MARCo (1986) e não no experimento aqui relatado, talvez se deva à espécie vetora envolvida na transmissão. Provavelmente o $M$. persicae tenha sido a espécie mais importante no trabalho acima citado, enquanto que no nosso, as espécies de Aphis e $S$. graminum, foram as mais importantes e devem ser menos sensíveis ou mesmo insensiveis a essa superfície reflectiva.

As condições climāticas e a velocidade de desenvolvimento das plantas também devem ser levadas em conta, pois, em regiões ou períodos chuvosos há perda de reflectividade em razão da lavagem da superfície foliar, havendo necessidade de novas pulverizações logo após as chuvas; por outro lado, plantas como a abobrinha de moita crescem rapidamente, principalmente no período inicial de desenvolvimento vegetati vo, portanto, as folhas e as brotações novas mais susceptiveis se expandem e crescem sem a proteção dos produtos reflectivos. Finalmente, os produtos repelentes, de aplicaŗão foliar, como os utilizados nos experimentos aqui descritos, não trouxeram vantagens na redução da disseminação da moléstia e, portanto, não 
são recomendados para esse uso. Há necessidade de outras pes quisas visando avaliar novos produtos.

\subsubsection{Efeito da casca de arroz aplicada em faixas nas linhas de plantio}

Experimento 1:

Os resultados deste experimento em que se apli cou casca de arroz em faixas de 0 (testemunha), 60 e $120 \mathrm{~cm}$, ao longo das linhas de plantio, em uma cultura comercial de abobrinha-de-moita cv. Caserta, podem ser vistos na. Tabela 13. Na Figura 5A, podem ser vistas as curvas das incidências semanais dos 3 tratamentos.

As primeiras plantas afetadas foram observadas fora das parcelas, no protocolo realizado no dia 11/05, 17 dias após o plantio. Na semana seguinte a primeira planta afe tada dentro das parcelas foi observada, em uma das testemunhas. O atraso na introdução do vírus no experimento foi de uma semana no tratamento em que se aplicou a casca de arroz em $50 \%$ da área (faixa de $60 \mathrm{~cm}$ ), em duas semanas no tratamen to em que se cobriu toda a área com casca de arroz (faixa de $120 \mathrm{~cm})$. A partir da primeira planta afetada, a disseminação foi aumentando, na testemunha, de uma forma relativamente constante, atingindo a incidência máxima $(56,2 \%)$ entre todos os tratamentos. Naquelas parcelas com faixas de 60 a $120 \mathrm{~cm}$ de casca de arroz, a incidência manteve-se baixa até 
Tabela 13. Efeito da casca de arroz aplicada em faixas de 2 larguras, no controle do VMM-Me, em cultura comercial de abobrinha-de-moita.

\begin{tabular}{|c|c|c|c|c|c|c|c|}
\hline \multirow[t]{3}{*}{ Data } & \multirow{3}{*}{ 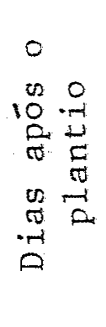 } & \multicolumn{6}{|c|}{$\begin{array}{l}\text { Relação entre numero de plantas expostas (ne) e infectadas } \\
\text { (ni), nos tratamentos em que se aplicou a casca de arroz en } \\
\text { faixas de } 0 \text { (testemunha), } 60 \text { e } 120 \mathrm{~cm} \text {, nas linhas de plantic } \\
\text { e respectivas porcentagens }(\%) \text {, nas datas indicadas. }\end{array}$} \\
\hline & & \multicolumn{2}{|c|}{0 (testemunha) } & \multicolumn{2}{|c|}{$60 \mathrm{~cm}$} & \multicolumn{2}{|c|}{$120 \mathrm{~cm}$} \\
\hline & & $n e / n i$ & $\%$ & $n e / n i$ & $\%$ & $\mathrm{ne} / \mathrm{ni}$ & $\%$ \\
\hline $11 / 05$ & 17 & $513 / 0 *$ & 0,0 & $524 / 0$ & 0,0 & $506 / 0$ & 0,0 \\
\hline $18 / 05$ & 24 & $506 / 1$ & 0,2 & $523 / 0$ & 0,0 & $503 / 0$ & 0,0 \\
\hline $25 / 05$ & 31 & $506 / 14$ & 2,8 & $523 / 1$ & 0,2 & $503 / 0$ & 0,0 \\
\hline $01 / 06$ & 38 & $506 / 19$ & 3,7 & $523 / 2$ & 0,4 & $501 / 1$ & 0,2 \\
\hline $08 / 06$ & 45 & $506 / 57$ & 11,3 & $523 / 18$ & 3,4 & $501 / 17$ & 3,4 \\
\hline $22 / 06$ & 59 & $506 / 128$ & 25,3 & $522 / 35$ & 6,7 & $501 / 20$ & 4,0 \\
\hline $06 / 07$ & 73 & $489 / 275$ & 56,2 & $519 / 194$ & 37,4 & $497 / 134$ & 27,0 \\
\hline
\end{tabular}

*Total de 3 repetições. 

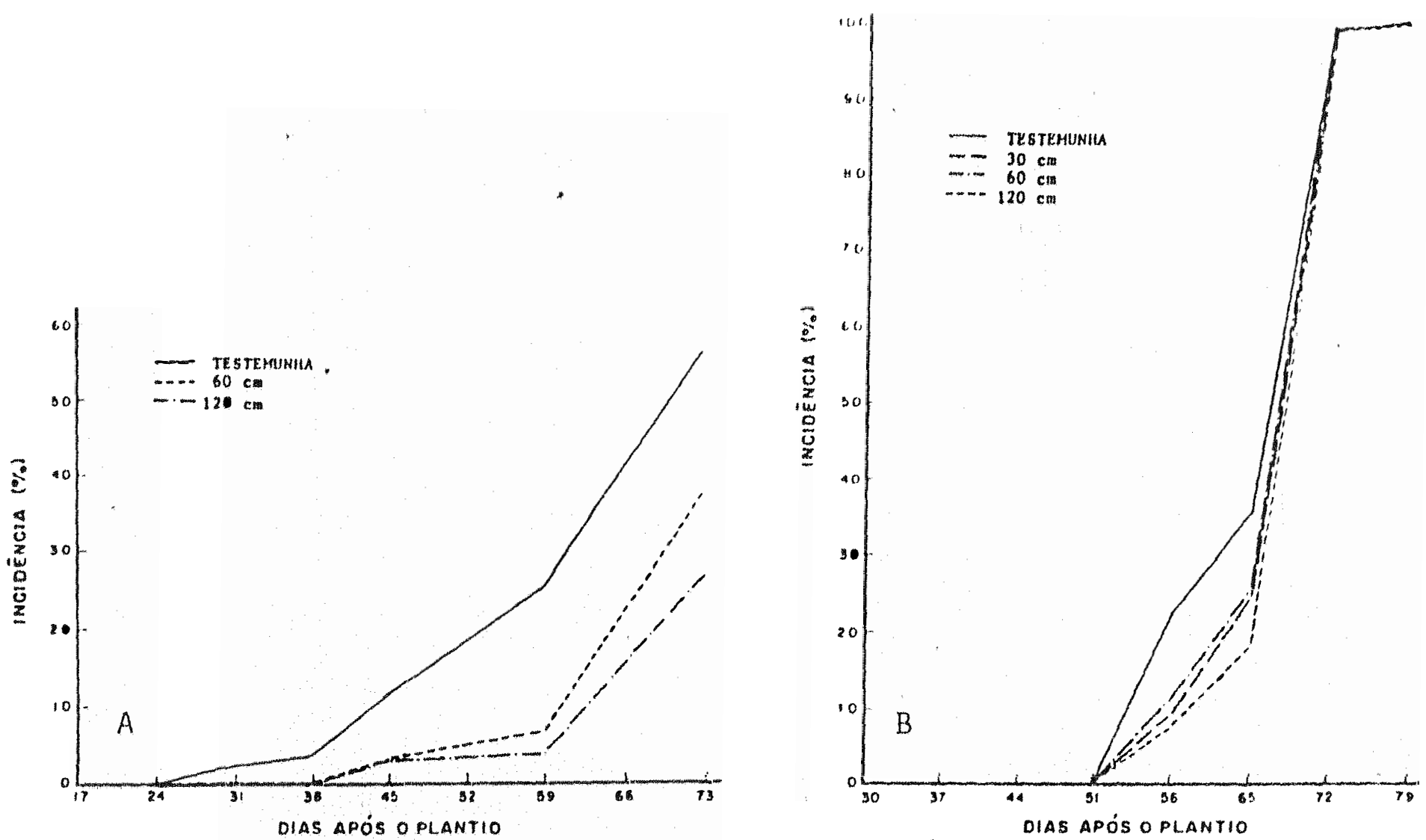

Figura 5. Efeito da casca de arroz aplicada em faixas nas linhas de plantio, no controle d. VMM-Me, em cultura de abobrinha-demoita. A-Faixas de O (testemunha), 60 e $120 \mathrm{~cm}$. B-Faixas de 0 (testemunha), 30,60 e $120 \mathrm{~cm}$. 
os 59 dias do plantio, verificando-se em seguida, um aumento relativamente elevado aos 73 dias. Observa-se uma redução significante dos dois tratamentos quando comparados com o con trole, mas entre os tratamentos praticamente não se verificou diferença.

\section{Experimento 2:}

Como o efeito da casca de arroz aplicada em fai xas de $60 \mathrm{~cm}$ foi comparável ao de faixas de $120 \mathrm{~cm}$ no experimento anterior, tencionou-se verificar no presente experimen to, o efeito de uma faixa de $30 \mathrm{~cm}$, reduzindo assim a quantidade de casca a ser utilizada no campo. Os resultados da incidência semanal do VMM-Me, total das 8 repetições, de cada tratamento podem ser observados na Trabela 14. Verifica-sé que o início da disseminação do virus foi bastante tardia. Quando as plantas iniciaram o florescimento, em 03/08, nenhuma das plantas se encontrava afetada pelo vírus, portanto, o período em que o vỉrus causa maior perda de produção já havia passado. Somente duas semanas após, quando se iniciaram as colhettas, verificaram-se plantas infectadas (Figura 6) e em incidências relativamente elevadas. A análise de variância das porcentagens médias, transformadas em arco seno raiz quadrada, nos dias $17 / 08$ e 24/08, quando as diferenças foram mais evidentes, mostraram signifiçância ao nível de 10\%, dos tratą mentos com casca de arroz, em comparação com a testemunha. Is to mostra que a casca de arroz, mesmo em faixas de $30 \mathrm{~cm}$, apa 
Tabela 14. Efeito da casca de arroz aplicada em faixas de 3 larguras, no controle do VMM-Me, em cultura comercial de abobrinha-de-moita.

\begin{tabular}{|c|c|c|c|c|c|c|c|c|c|}
\hline \multirow[t]{3}{*}{ Data } & \multirow{3}{*}{ 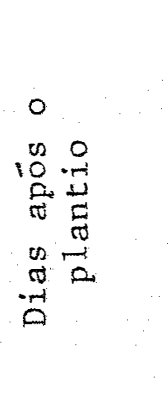 } & \multicolumn{8}{|c|}{$\begin{array}{l}\text { Relação entre número de plantas expostas (ne) e numero de } \\
\text { plantas infectadas (ni) em cada um dos tratamentos em que } \\
\text { se aplicou casca de arroz em faixas de } 0 \text { (testemunha), } 30, \\
60 \text { e } 120 \text { cm nas linhas de plantio e as respectivas porcenta } \\
\text { gens }(\%) \text {, nas datas indicadas. }\end{array}$} \\
\hline & & \multicolumn{2}{|c|}{0 (testemunha) } & \multicolumn{2}{|c|}{$30 \mathrm{~cm}$} & \multicolumn{2}{|c|}{$60 \mathrm{~cm}$} & \multicolumn{2}{|c|}{$120 \mathrm{~cm}$} \\
\hline & & $n e / n i$ & $\%$ & $n e / n i$ & $\%$ & $n e / n i$ & $\%$ & ne/ni & $\%$ \\
\hline $20 / 07$ & 30 & $77 / 0 *$ & 0,0 & $78 / 0$ & 0,0 & $80 / 0$ & 0,0 & $78 / 0$ & 0,0 \\
\hline $27 / 07$ & 37 & $76 / 0$ & 0,0 & $75 / 0$ & 0,0 & $79 / 0$ & 0,0 & $78 / 0$ & 0,0 \\
\hline $\begin{array}{l}03 / 08 \\
\text { (floresc }\end{array}$ & $\begin{array}{l}44 \\
\text { cimento) }\end{array}$ & $76 / 0$ & 0,0 & $75 / 0$ & 0,0 & $79 / 0$ & 0,0 & $78 / 0$ & 0,0 \\
\hline $10 / 08$ & 51 & $76 / 0$ & 0,0 & $75 / 0$ & 0,0 & $79 / 0$ & 0,0 & $78 / 0$ & 0,0 \\
\hline $\begin{array}{l}17 / 08 * * \\
\text { (colheit }\end{array}$ & $\begin{array}{r}58 \\
\text { ta) }\end{array}$ & $76 / 19$ & 25,0 & $75 / 7$ & 9,3 & $79 / 9$ & 11,4 & $78 / 6$ & 7,7 \\
\hline $24 / 08 * *$ & 65 & $74 / 30$ & 40,5 & $73 / 18$ & 24,6 & $78 / 20$ & 25,6 & $76 / 14$ & 18,4 \\
\hline $31 / 08$ & 72 & $73 / 73$ & 100,0 & $71 / 70$ & 98,7 & $75 / 74$ & 98,7 & $74 / 74$ & 100,0 \\
\hline $08 / 09$ & 79 & $73 / 73$ & 100,0 & $71 / 71$ & 100,0 & $75 / 75$ & 100,0 & $74 / 74$ & 100,0 \\
\hline
\end{tabular}

*Total de 8 repetições.

**As análises de variância das médias destas datas, transformadas em arco seno raiz quadrada das porcentagens, mostraram. significância ao nível de $10 \%$, em relação ao controle. 


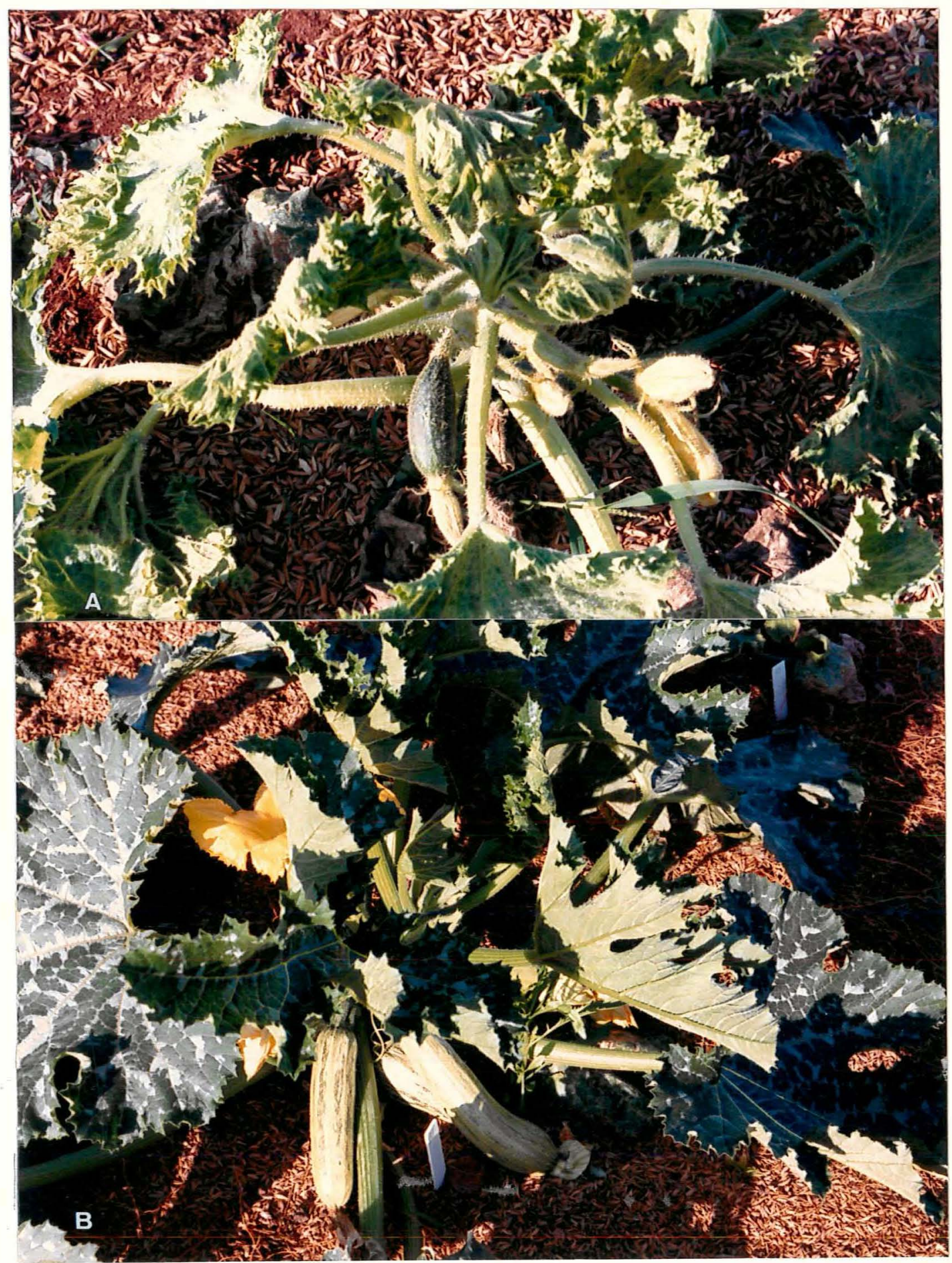

Figura 6. Plantas de abobrinha-de-moita no ensaio com superfície reflectiva de casca de arroz. A - Planta infectada.:B Planta sadia. 
rentemente ainda apresentava o mesmo efeito dos tratamentos om faixas mais largas, reduzindo significativamente a incidēncia. Estas diferenças podem ser melhor observadas na Eigura 5B. Elas são maiores nessas duas datas. Na semana seguin te as incidências são praticamente semeihantes, e extremamente altas, podendo-se dizer que toda a cultura já se encontra afetada com o vírus de maneira generalizada. Do modo que a disseminação do VMM-Me ocorreu neste experimento verifica-se que a pressão de inóculo foi muito grande em um período de apenas duas semanas. E provável que grandes revoadas de afídeos vetores tenham ocorrido uma ou duas semanas antes, causando essa enorme disseminação.

A produção de frutos, em gramas, em cada uma das 8 repetiçōes podem ser observadas na Tabela 15. Em virtude de o início das infecções ter sido bastante tardio, após - florescimento, não se realizou a análise estatística desses resultados, pois, qualquer diferença significativa seria devido a outros fatores que não ao vírus. Por essa tabela veri fica-se que, de uma maneira geral, a produção foi relativamen te maior nos tratamentos em que se aplicou casca de arroz no solo do que na testemunha, sem cobertura alguma. Este fato provavelmente se deve ao benefício que a cobertura morta traz às plantas, retendo a umidade do solo por mais tempo. A faixa mínima de apenas $30 \mathrm{~cm}$ já. foi suficiente para dar a produção máxima, comparável aos outros tratamentos em que se aplicou casca de arroz em faixas mais largas. 
Tabela 15. Efeito da casca de arroz aplicada em faixas, na produção da abo brinha-de-moita.

\begin{tabular}{|c|c|c|c|c|c|c|}
\hline \multirow{2}{*}{$\begin{array}{l}\text { Repeti- } \\
\text { ções }\end{array}$} & \multicolumn{6}{|c|}{$\begin{array}{l}\text { Produção de frutos de abobrinha (em gramas) nas parcelas em que } \\
\text { se aplicou casca de arroz em faixas de } 0 \text { (testemunha), } 30,60 \text { e } \\
120 \mathrm{~cm} \text {. }\end{array}$} \\
\hline & 0 (testemunha) & 30 & & 60 & 120 & \\
\hline 1 & $21.085(10)$ & 31.980 & $(10)$ & $24.845(10)$ & 21.640 & $(10)$ \\
\hline 2 & $23.500(10)$ & 21.495 & $(10)$ & $19.945(10)$ & 21.580 & $(08)$ \\
\hline 3 & $13.255(09)$ & 21.085 & $(09)$ & $25.005(10)$ & 21.645 & (10) \\
\hline 4 & $11.870(09)$ & 15.875 & $(10)$ & $21.835(10)$ & 28.660 & $(10)$ \\
\hline 5 & $17.880(10)$ & 18.905 & $(10)$ & $18.065(10)$ & 20.400 & $(10)$ \\
\hline 6 & $12.365(10)$ & 22.200 & $(10)$ & $22.735(10)$ & 23.560 & $(10)$ \\
\hline 7 & $15.800(10)$ & 19.550 & $(10)$ & $21.270(10)$ & 15.370 & $(10)$ \\
\hline 8 & $13.250(09)$ & 26.315 & $(10)$ & $19.355(10)$ & 23.215 & $(10)$ \\
\hline Total & $129.005(77)$ & 177.405 & $(78)$ & $173.055(80)$ & 176.070 & $(78)$ \\
\hline $\begin{array}{l}\text { Média/ } \\
\text { parcela }\end{array}$ & 16.125 & 22.175 & & 22.631 & 22.008 & \\
\hline $\begin{array}{l}\text { Médial } \\
\text { planta }\end{array}$ & 1.675 & 2.274 & & 2.263 & 2.257 & \\
\hline
\end{tabular}

Obs.: O nümero entre parênteses representa o nümero de plantas da parce $1 a$. 
Os resultados obtidos nos dois experimentos mos tram que a casca de arroz tem como efeito principal o de retardar a entrada da moléstia na cultura, como já observado pela maioria dos pesquisadores que testaram superficies reflectivas. Seu efeito é melhor justamente no periodo em que as plantas novas são mais susceptiveis à infecção e quando afetadas produzem significativamente menos (YUKI \& COSTA ${ }^{l}$ ). Quando o efeito do tratamento começa a desaparecer as plantas $j a ́$ passaram do período de florescimento e infecções posteriores não trazem mais prejuízos à produção. A grande vantagem, portanto, desse método, é atrasar o desenvolvimento da doença, retardando o início das infecçōes em 1 a 2 semanas, poden do mesmo retardar por 30 dias (COSTA \& COSTA, 1971), dependen do das condições de aisseminação da moléstia.

\section{MESSIAEN et alii (1967) e ADLERZ \& EVERETT (1968)}

verificaram que quanto maior a área coberta com superficies alu minizadas, maior a eficiência no controle. Nas condições em que foram conduzidos os experimentos, não foi verificada essa tendência. Faixas relativamente estreitas, como a de $30 \mathrm{~cm}$, aparentemente foram suficientes para dar um efeito máximo ao controle.

O modo pela qual a casca de arroz evitou a dis seminação precoce do vírus é desconhecida. As espécies de

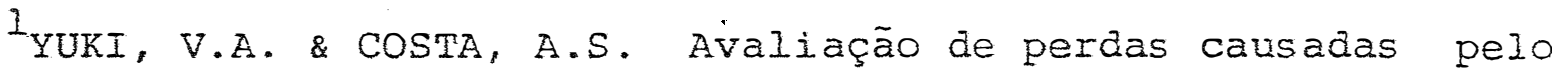
VMM-Me, em abobrinha-de-moita cv. Caserta, 1990 (dados não publicados.
} 
Aphis e S. graminum, vetores considerados mais importantes na epidemiologia do virus, mostraram-se, em relação a M. persicae, relativamente pouco sensíveis e indiferentes à casca de arroz (Costa, 1970b). Três hipóteses foram formuladas: a primeira é de que como a maior proporção dos vetores pertence às espécies de Aphis e S. graminum, como já foi demonstrado anteriormente, embora menos sensíveis que algumas outras espécies vetoras, o grau de repelêncìa, já seria suficiente pa ra reduzir a incidência do vírus. A segunda hipótese é de que, ao contrário do conceito geral de que a casca de arroz re pele os afídeos, ela estaria atraindo-os. Eles desceriam sobre a casca de arroz e, ao realizar as picadas de prova, dani ficariam seus estiletes, tornando-se incapazes de se alimentar nos vōos subsequentes, ou ainda, nessas picadas sobre essas superficies haveria uma certa limpeza dos estiletes. fato de a casca de arroz estar atraindo os vetores, poderia estar reduzindo também o número de afídeos que descem sobre as plantas de abobrinha, pois, sabe-se que o nümero de afídeos que descem por unidade de área se torna tanto menor quanto maior essa superfície atrativa (COSTA \& LEWIS, 1967), portanto, a pressão de inóculo se reduziria. Finalmente, a terceira hipótese é de que no período em que foram conduzidos os ex perimentos (maio/junho a julho/setembro), nem o grupo das espécies de Aphis, nem S. graminum, teria importância epidemiológica, devido à sua baixa população alada em revoada. A disseminação da moléstia estaria sendo feita por outras espé- 
cies mais sensiveis à reflexão da casca de arroz, como seria - caso do $M$. persicae, conforme já demonstrado por $\cos \mathrm{TA}$ (1972b) e tambēm porque é no inverno que se verificam as maiores revoadas desse eficiente vetor. Pesquisas estão sen do conduzidas visando esclarecer o assunto.

Os dois experimentos de casca de arroz aqui re latados foram conduzidos dentro dos períodos de menores inci dências do VMM-Me. Isto não foi feito propositalmente, mas respeitando o período de plantio do próprio produtor que, mes mo correndo risco de geadas, preferia tentar a produção nessa época, visando obter melhores preços. Por outro ladó ainda, esse produtor achava bastante dificil produzir abobrinha do tipo italiano em outras épocas devido ao mosaico, preferindo plantar outras espécies mais resistentes, como a cv. menina. Nas condições em que foram conduzidos os dois experimentos, a casca de arroz aplicada em faixas de no minimo $30 \mathrm{~cm}$, ao longo das linhas de plantio, mostrou ser um bom método de controle. Além disso, é barato e de efeito relativamente prolongado na cultura, até pelo menos o início do florescimento. Traz ainda as vantagens da cobertura morta e não causa poluição ao meio ambiente. E provável que este método possa ser utilizado em outras culturas que tenham proble mas de fitoviroses transmitidas por afídeos. 


\section{CONCLUSÕES}

- o grupo de espécies de Aphis representou 47,1\% do total dos afídeos coletados no período de 1984 a 1988 . S . graminum representou $20,5 \%$, Rhopalosiphum spp. 6,9\% e M. persicae $6,5 \%$.

- As ēpocas de revoadas mais densas foram mais ou menos definidas no ano, de acordo com cada espécie ou grupo de espécies.

- Os períodos de maiores incidências da moléstia ocorreram nos meses mais quentes do ano, ou seja, do final da primavera (novembro) até meados de outono (maio). As.curvas revoadas de Aphis spp. e S. graminum foram as que apresenta ram as melhores correlaçõesgráficas com a da incidência do VMMMe. As de M.persical eRhopalosiphum spp. não apresentaram correlação.

- M. persical foi experimentalmente a espécie vetora mais eficiente na transmissão do VMM-Me, seguida por 
A. fabae solanella, S. graminum, A. craccivora, A. gossypii e A. spiraecola.

- Os inseticidas carbamatos Aldicarb e Carbof $\underline{\underline{Z}}$ ran reduziram a incidência do vĩrus, mas não suficientemente para que pudessem ser recomendados. O inseticida carbamato Pirimicarb, o óleo vegetal (Natur'oil) e o mineral(Triona B), a purpurima dourada e a prateada e ainda a água de cal, não reduziram a incidência do vírus.

- A casca de arroz reduziu significativamente a incidência do VMM-Me, mesmo quando aplicada em. faixas de $30 \mathrm{~cm}$ ao longo das linhas de plantio. Nessa quantidade a utiliza ção da casca de arroz torna-se praticamente viável em āreas relativamente grandes. 


\section{REFERẼNCIAS BIBLIOGRÁFICAS}

ADLERZ, W.C. Spring aphid flights and incidence of watermelon mosaic virus 1 and 2 in Florida. Phytopathology, St. Paul, 64: 350-353, 1974 .

ADLERZ, W.C. \& EVERETT, P.H. Aluminum foil and white polyethylene mulches to repel aphids and control watermelon mosaic. Journal of Economic Entomology, washington, 6l: $1276-1279, \quad 1968$.

ALBUQUERQUE, F.C.; IKEDA, H.; COSTA, A.S. Ocorrência do vírus do mosaico da melancia (Citrullus vulgaris schrad.) em plantações de melão (Cucumis mel L.) na região de BelémPA. Revista de Olericultura, Fortaleza, 12: 94, 1972 (resumo).

ANDERSON, C.W. Two watermelon mosaic virus strains from Central Florida. Phytopathology, St. Paul, 44: 198-202, 1954 .

ĀVILA, A.C. Viroses das cucurbitáceas. Informe Agropecuārio, Belo Horizonte, ㅇ: 52-53, 1982. 
BLACKMAN, R.L. \& EASTOP, V.F. Aphids on the world's crop: an icentification and information guide. Chichester, John wiley \& Sons, 1984. 413p.

BRADIEY, R.H.E.; WADE, C.V.; WOOD, E.A. Ephid transmission of potato virus $Y$ inhibited by oils. Virology, New York, 18: $327-328, \quad 1962$.

BROADBENT, L. The correlation of aphid numbers with spread of leaf roll and rugose mosaic in potato crops. Annals of Applied Biology, Cambridge, 37: 58-65, 1950.

BROADBENT, L. Insecticidal control of the spread of plant viruses. Annual Review of Entomology, Palo Alto, 2: $339-$ $407, \quad 1957$.

CHALFANT, R.B.; JAWORSKI, C.A.; JOHNSON, A.W.; SUMMER, D.R. Reflective film mulcies, millet barriers, and pesticides effects on watermelon mosaic virus, insects, nematodes, soil borne fungi, and yield of yellow summer souash. Joumal of the American Society for Horticultural Science, St. Josepi, 102: 11-15, 1977.

COSTA, A.S.; CARVALHO, A.M.B.: COSTA, C.I.; NAGAI, H. NiOléstias de virus ào tomateiro. Boletim dio Campo (Blemco), Rio de Janeiro, 183: 8-26, 1964.

COSTA, A.S. ; KITAJIMF, E. Hi.: NPGAI, H. Alguns virus que afe tam opepino (Cucumis sativus L.) em são paulo. Fevista de Olericultura, Fortaleza, 12: 100-101, 1972 (Resumo).

CostA, C.L. Nota prévìa sobre a redução da disserinação dos virus de planta, pelo efeito repelente de certas cores aos afideos vectores. Revista a Socjedade Brasileira de Fitopatologia, Campinas, 3: 49-50, 1969 a (Resumo). 
CostA, C.L. Ocorréncia, no Estado de são Paulo, de forma sexuada de Myzus persicae, importante vector de virus de piantas. Revista da Sociedade Brasileira de Fitopatologia, Campinas, $\underline{3}$ : 59-60, 1969 b (Resumo).

CostA, C.I. Variações sazonais da migração de Múzus persicoe em Campinas, nos anos de 1967 a 1969 . Bragantia, Campinas, 29: 347-359, 1970 .

Costi, C.L. Controle de moléstias de vírus de plantas com superficies reflectivas repelentes ao vector. Revista Peruana de Entomologia, Lima, 15: 135-139, 1972 a.

COSTA, C.I. Emprego de superficies reflectivas repelentes aos aíideos vectores, no controle das moléstias de vírus de plantas. Piracicaba, 1972b. 94p. (Doutorado - Escola Superior de Agricultura "Luiz de Queiroz"/USP).

COSTA, C.I. \& CosTA, A.S. Redução da disseminação de mosaico em abóbora de moita (Cucunbita pepo var. melopepo) com superficies reflectivas repelentes aos afideos vectores. ReVista de Olericultura, Piracicaba, II: 24-25, 1971 (Resumo) .

Costa, C.I. \& CostA, A.S. Espécies de afídeos mais írequente mente coletadas em Campinas, numa armadilha amarela dea àqua, nos anos de 1967 a 1971. In: REUNIÃO DE ENTOMOLOGIA AGRIColA, 1, Itabuna, 21-25 fev. 1972a. (Resumo).

COSTA, C.I. \& CoSTA, A.S. Variações sazonais àa migração de seis grupos comuns de aíidios nos anos de 1967 a 1971 , em Campinas, SP. In: REUNIÃO DE ENTONOLOGIA AGRICOLA, I, Itabuna, 21-25 ₹ev. 1972b. (Resumo). 
COSTA, C.I.; Cupertino, F.P.; COSTA, A.S.; LEITE, N. Efeito de inseticidas sistêmicos no controle do virus do enrolameito da folha em batatal para semente. O Biológico, são Paulo, 37: 165-167, 1971.

COSTI, C.L. \& LENIS, I. The relationships between the size of yeliow traps anö catches of aphids. Ertomologia Exierimentalis Applicata, Amsterajan, I0: 485-487, 1967.

CRESTANI, O.; BRAGUINI, M.T.; LIN, M.T.; SĀ, P.B.; KITAJIMA, E.W. Dados preliminares sonre um potyvirus de cucurbitácea, tentativamente identificado como mosaico da melancia 2 ("watemelon mosaic virus 2"). In: VIROLOGIA 87 - ENCONTROL REGIONAL NORDESTE DE VIROLOGISTAS, Maceiö, 1987.

DAIBER, C.C. \& DONALDSON, J.M. Watermelon mosaic virus in vegetable marrows: The effect of aluminum foil on the vector. Phytophylactica, Pretoria, 8: 85-86, 1976.

DICKSON, R.C. \& LAIRD Jr., E.F. Aluminum soil to protect melons from watermelon mosaic virus. Plant Disease Reporter, Beltsville, 50: 305, 1966.

GEORGE, W.I. \& KRING, J.B. Virus protection of late season summer squash with aluminum mulch. Conecticut Agricultural Experiment Station, New Haven, Circular no 239, $1971.8 p$.

INSTITUTO AGRONÔMICO. InstruçÕes agrícolas para o Estado de São Paulo. Boletim 200, 4.ed., Campinas, 1987. 231p.

IRWIN, M.E. \& GOODMAN, R.M. Ecology and control of soybean mosaic virus. In: MARAMOROSCH, K. \& HARRIS, K.P., eds., Plant Diseases and Vectors: Ecology and Epidemiology. Aca demic Press, New York, 1981. p.181-220. 
JOHNSON, C.G. \& TAYLOR, L.R. The development of large suction traps for airborne insects. The Annals of Applied Biology, Cambridge, 43: 51-62, 1955.

KRING, J.B. New ways to repel aphids. Frontiers of Plant Science, New Haven, 17: 6-7, 1964.

KRING, J.B. Determining the number of aphids over reflective surfaces. Journal of Economic Entomology, Washington, 63: $1350-1353,1970$.

KRING, J.B. Flight behaviour of aphids. Annual Review of Entomology, Palo Alto, 17: 461-492, 1972.

LIN, M.T.; KITAJIMA, E.W.; MUNHOZ, J.O. Isolamento e proprie dades do virus da necrose da abóbora, um possivel membro do grupo "Tobacco Necrosis Virus". Fitopatologia Brasileira, Brasilia, 8: 622, 1983 (Resumo).

LOVISOLO, $O$. Virus and viroid diseases of cucurbits. Acta Horticulture, Wageningen, 88: 33-71, 1981.

MARCO, S. Incidence of aphid transmitted virus infection reduced by whitewash sprays on plants. Phytopathology, st. Paul, 76: 1344-1348, 1986.

MARROU, J. \& MESSIPEN, C.-M. Essai de protection des cultures de melon et de courgette contre le virus de la mosaique du cocombre. Annales des Ephiphyties, Paris, 19 (no hors serie): 147-157, 1968. 
MESSIAEN, C.-M.; MARROU, J.; MASSON, P.; DUTEIL, M. Essais de protection des cultures de melon contre de virus de la mosaique du cocombre. Effect bénéfique de la converture du sol des films plastiques refléchissants. Comptes Rendus des Searches de l'Academie D'Agriculture de France, Paris, 53: 103-109, 1967.

MILNE, K.S. \& GROGAN, R.G. Cinaracterization of watermelon mosaic virus strains by serology and others properties. Phytopathology, st. Paul, 59: 809-818, 1969.

MOERICKE, V. IX Neue untersuchungen thoer das farbsehen des flugs von blattausen, insbesondere der pfirsichblattaus, Muzodes persicae (sulz.). Nachr.bl. atsch. Pfl. schutzd. Braumchuweig, 3: 23-24, 1954.

MOERICKE, V. Der flug von indekten uber pflanzenbecachsenen flachen. Zeitschrift fur Pflanzenkrankheiten und Pflan zenschultz, Bonn, 64: 507-514, 1957.

MOORE, W.D.; SMITH, F.F.; JOHNSON, G.V.; WOLDENBARGER, W. O. Reduction of aphid population and delayed incidence of virus infection on yellow straigth neck squash by the use of aluminum foil. Proceedings of Florida state Horticultural Society, Miami Beach, 78: 187-191, 1965.

PAVAN, M.A. Virus do mosaico da melancia: purificação, varia bilidade e distribuição nas principais regiões produtoras de pepino e abobrinina de Minas Gerais. Viçosa, 1985. 69p. (Boutorado - universidade Federal de Viçosa).

PURCIFUIL, D.E.; EDWARDSON, J.R. ; HIEBERT, E.; GONSALVES, D. Papaya ringspot virus. CMI/AAB Description of Plant Viruses, Ferry Lane, 1984. 8p. 
RACCHAH, B. Non persistent viruses: epidemiology and control. Advances in Virus Research, New York, 31: 387-429, 1986.

SE, P.B.; DUSI, A.N.; MARINHO, L.A.; KITAJIMA, E.W. Comparação entre isolados dos vírus do mosaico do mamoeiro estirpe melancia (PRSV-W) e o virus do mosaico da melancia 2 (WV-2). Fitopatologia Brasileira, Brasilia, 14: 114 , 1989 (Resumo).

SAKO, N.; OKUMURA, T.; NONAKA, F. Aphid transmission of watermelon mosaic virus. Agricultural Bulletin of Saga University, Saga, no 42, $1977 . \quad 8 p$.

SIMONS, J.N. \& ZITTER, T.A. Use of oils to control aphidborne viruses. Plant Disease, St. Paul, 64: 542-546, 1980.

SMITH, F.F.; JOHNSON, G.V.; KAHN, R.P.; BING, A. Repellency of reflective aluminum to transient aphid virus - vectors. Phytopathology, St. Paul, 54: 748, 1964 (Abstract).

TAYLOR, L.R. The absolute efficiency of insect suction traps. The Annals of Applied Biology, Cambridge, 50: $405-421$, 1980 .

VAN REGENMORTEL, M.H.V.; BRANDES, J.; BERCKS, R. Investigations on the properties of watermelon mosaic virus. Phytopathologische Zeitschrift, Berlin, 45: 205-216, 1962.

WOIEENBARGER, D.O. \& MOORE, W.D. Mulch treatments of squash and tomatoes with respect to virus infections and yield. Proceedings of Florida state Horticultural Society, Miami Beach, 80: 217-221, 1967. 
WYMAN, J.A.; TOSCANO, N.C.; KIDO, K.; JOHNSON, H.; MAYBERRY, K. Effects of mulching on the spread pf aphid-transmitted watermelon mosaic virus to summer squash. Journal of Economic Entomology, washington, 72: 139-143, 1979.

YUKI, V.A. \& COSTA, A.S. Ocorrência do afídeo Rhopalosiphum rufiabdominalis em raizes de abobrinha de moita var. Caser ta, em são Paulo. In: CONGRESSO BRASIIEIRO DE ENTOMOLO GIA, 12., Belo Horizonte, 22-29 jan. 1989a. Resumos. p. 100 .

YUKI, V.A. \& COSTA, A.S. Transmissão de um potyvirus que cau sa mosaico em abóbora de moita pelo pulgão da raiz, Rhopalosiphum rubiabdominalis. Summa Phytopathologica, Jaguariūna, 15: 40, 1989b (Resumo).

YUKI, V.A.; COSTA, A.S.; BULISANI, E.A.; DE NARDO, E.A.B. Redução da incidência precoce do mosaico douraủo do feijoeiro através do controle da mosca branca vetora por meio de inseticidas. Sugria Phytopatjologica, Jaguariúna,15:-139-144, 1989.

YUKI, V.A.; ROSSETTO, C.J.; COSTA, A.S. Ocorrência provável do biótico $C$ do Schizaphis graminum em são Paulo. In: CONGRESSO BRASILEIRO DE ENTONOLOGIA, 6., Campinas, 3-9 fev. 1980. (ke sumos), P. 154-155.

ZITTER, T.A. \& SIMONS, J.N. Management of viruses by alteration of vector efficiency and by cultural practices. Annual Review of Phytopathology, Palo Alto, 18: 239-310,1980. 